\title{
ANÁLISIS Y CARACTERIZACIÓN DEL THRONOS EN EL MUNDO ROMANO. LOS CASOS HISPANOS
}

\author{
ANALYSIS AND CLASSIFICATION OF THE THRONOS IN THE \\ ROMAN WORLD. THE HISPANIC EXAMPLES
}

\author{
ANA PORTILLO GÓMEZ*
}

Resumen: La importancia, singularidad y escasez de este tipo de elementos escultóricos nos ha llevado a plantear un estudio sistemático del thronos, como objeto ligado al poder y la ritualidad romana. En los últimos años y gracias al avance de la actividad investigadora y de las continuadas actuaciones en distintos yacimientos arqueológicos, hemos asistido al hallazgo de algunas de estas piezas en distintos puntos del marco geográfico hispano. Estos elementos dotan a sus correspondientes contextos de un gran significado, aportando una información esencial sobre las funciones, carácter y monumentalidad de los espacios que originalmente los albergaron. Por ello hemos creído necesario realizar un breve recorrido por la historia de estos soportes, intentando elaborar una clasificación según sus características formales, así como aportar datos inéditos y observaciones de distintos casos recientemente descubiertos en la península ibérica.

Palabras clave: Escultura clásica, trono, mobiliario romano, religión romana, Hispania.

\section{INTRODUCCIÓN}

Los tronos marmóreos constituyen uno de los elementos escultóricos más claros de la práctica de ceremonias religiosas concretas en el mundo romano. Son

\footnotetext{
* Departamento de Historia del Arte, Arqueología y Música
} (Universidad de Córdoba). Facultad de Filosofía y Letras, Plaza del

\begin{abstract}
The importance, singularity and paucity of this type of sculptural elements have led us to propose a systematic study of the thronos, as an object related to power and Roman rites. In the last few years and thanks to research activities and works on different archaeological sites, some of these pieces have appeared in the Hispanic geography. This fact gives a great significance to these contexts, providing coherence and essential information about the functions, nature and monumentality of these places. That is why it is necessary to make a brief overview through the history of these thronoi, trying to elaborate a classification according to their formal characteristics, as well as to provide unpublished data and observations of different cases recently discovered in the Iberian Peninsula.
\end{abstract}

Keywords: Classical sculpture, throne, Roman furniture, Roman religion, Hispania.

por tanto, una manifestación evidente de la ritualidad y creencias de esta civilización. Según Eugenio La Rocca (2007: 100), uno de los lugares idóneos para la ubicación de este tipo de piezas es, precisamente, un templo dedicado a un emperador divinizado. La presencia de

Cardenal Salazar, 3, 14071 Córdoba, España. Correo-e: aportillogomez@gmail.com. 
dichos tronos podría estar conmemorando a los dioses que participarían simbólicamente en las ceremonias reservadas a las nuevas divinidades con motivo de sellisternia o lectisternia celebrados en su honor (Bell 2009: 71-74). Por otro lado, la existencia de estos soportes también puede traducirse como la epifanía de los dioses pudiendo, a través de ellos, estar presentes tanto en espacios sacros, como en ámbitos relacionados de alguna manera con la religiosidad, tales como teatros, anfiteatros o circos, lugares donde suelen concluir muchas ceremonias religiosas, habilitándose, en muchos casos, un pequeño recinto religioso dedicado a los dioses y a ensalzar a la familia imperial (Trillmich 2007: 419-422).

En líneas generales, el estudio de este tipo de mobiliario litúrgico ha sido poco abordado por la comunidad científica debido, de un lado, a la escasez de estos elementos en el ámbito hispano y de otro, a la confusión interpretativa, ya que en muchas ocasiones, estas piezas han sido entendidas como placas relivarias, hecho que ha provocado que muchos de estos fragmentos permanezcan sepultados en los fondos de no pocos Museos arqueológicos como elementos meramente ornamentales. Es pues objetivo de este estudio la revisión de las piezas que respondan a esta tipología, conocidas en el contexto de Hispania, así como dar a conocer otras tantas, fruto de nuevos hallazgos e interpretaciones.

\section{ORIGEN, FUNCIÓN Y SIGNIFICADO DEL THRONOS EN LA ANTIGÜEDAD}

El thronos de origen griego se trata de un tipo de mobiliario únicamente empleado por personajes pertenecientes a las élites sociales o por héroes y dioses (Richter 1966: 13) (fig. 1). Se define, por tanto, como un tipo de asiento honorífico con respaldo y escabel, en los que encontraremos a menudo un refinado y elaborado trabajo en las patas (La Rocca 2007: 83; Balil 1975: 71). $\mathrm{Si}$ bien podemos considerar el respaldo como un elemento característico de la morfología del thronos, es conveniente destacar que existen numerosos casos de sellae (sillas o taburetes rectangulares, de cuatro patas y sin respaldo) que presentan un trabajo y uso propios del thronos, es decir, han sido dotadas de ese halo honorífico y solemne característico de estos asientos. Esto es, contienen una elaborada y esmerada talla y ornamentación en las patas y suelen asociarse a personajes relevantes tales como emperadores (Claudio, Museo Arqueológico de Nápoles) o divinidades (Divus Augustus, Museo Arqueológico de Nápoles o Terra Mater de Mazarrón, Museo Arqueológico Provincial de Murcia).
En el asiento de estos muebles es frecuente encontrar un cojín sobre el que se sitúa directamente la imagen. En muchas ocasiones, dichos cojines suelen ir cubiertos con un amplio manto que cuelga por los extremos laterales, engalanándolo y aportando una cierta suntuosidad. Estos asientos contaban en el ámbito greco-romano con varios usos, entre ellos podemos destacar la celebración de un tipo de ceremonia religiosa concreta, los sellisternia o lectisternia, en función de si se empleaba un asiento o un lecho. Se trataba de una ceremonia de carácter propiciatorio realizada con motivo de imploraciones públicas tras una calamidad o una derrota militar (supplicatio) o bien, para conmemorar y dar la bienvenida a nuevas deidades al panteón. En el mundo griego estas celebraciones recibían el nombre de theoxenia, según nos transmite Pindaro (Ol., III) y consistían en celebrar la llegada de los dioses a la ciudad con la realización de sacrificios y banquetes, en los que se servía comida a las divinidades en una mesa engalanada (La Rocca 2007: 79, nota 11).

El rito consistía en la celebración de un banquete (epulum) en el que los dioses se encontraban presentes a través de sus atributos o símbolos característicos (exuviae deorum) (Madigan 2013: 87, fig. 44 y 45 ), de la representación de pequeñas figuras (simulacra) o las cabezas de los mismos (capita deorum). Dichos elementos solían colocarse sobre estos soportes, dando lugar con ello a la epifanía de la divinidad. Según Tito Livio $(5,13)$ el primer lectisternium celebrado en Roma tuvo lugar en el año 399 a.C., con motivo de un funesto verano que resultó fatal para hombres y bestias a consecuencia de una peste. Posteriormente contamos con noticias de otros tantos lectisternia celebrados en años sucesivos, como los del año 364 a.C. (Liv. 7, 2), 348 a.C. y 326 a.C. (Liv. 7, 27; 8, 25). Resulta interesante saber cómo estas ceremonias fueron restablecidas en tiempos de Augusto en la forma primitiva de sellisternia, durante los juegos seculares del año 17 a.C. (Guillén 2004: 112).

Las divinidades y héroes estaban igualmente presentes a través de estos pulvinaria (lechos o asientos decorados con cojines) en todo tipo de ludi, a los que eran transportados en ferculum o tensa (fig. 2). En estos casos los dioses podían representarse a través de pequeñas figuras portátiles, imágenes procesionales de los mismos, que solían ser réplicas de menor formato de las esculturas de culto que se encontraban en el interior de los templos. En otras ocasiones, la divinidad era representada por el trono únicamente, sobre el que se colocaban sus atributos para ser identificada (Bell 2007: 253, fig. 4; 254, fig. 5 y 6; Foletti 2011-2012: 36), tales son 
los casos de las representaciones que encontramos en el templo de Magna Mater en el Palatino (fase augustea), del que conocemos la imagen del frontón gracias a uno de los cinco relieves marmóreos conservados en la fachada de la Villa Medici (Roma), donde se representa la fachada de este templo (serie atribuida, al menos en un primer momento, al Ara Pietatis Augustae); o en el templo de Júpiter Capitolino (en la etapa correspondiente a finales del siglo I d.C.), reconocido por A. Levi (1931: 74-75, no 166, tav. LXXXIV) entre los mármoles del Palazzo Ducal de Mantua. En este sentido, debemos relacionar este tipo de representaciones con la tradición helenística de adorar a los soberanos a través de tronos vacíos sobre los que eran colocadas sus insignias, funcionando de este modo como una presencia simbólica del gobernante. Un ejemplo de ello lo encontramos en la veneración de Alejandro Magno a través de un trono transmitida por Plutarco (Eum., 13) (La Rocca 1994; Foletti 2011-2012: 36).

Nos dice Servio (Ad. Georg. 3, 533) que estos pulvinaria son los lechos que suelen prepararse específicamente en los templos, por lo tanto debemos siempre asociar este tipo de mobiliario a las construcciones sacras y con un uso predominantemente ritual. En Grecia estos tronos marmóreos eran también empleados como asientos de los sacerdotes en el interior o exterior de los templos, desde los que podían contemplar y vigilar sus dominios, acompañando y protegiendo así a las esculturas divinas. En este sentido cabe destacar el caso del templo de Apolo en cabo Zoster (Ática, Grecia), donde en el interior de la cella fue hallado un trono de mármol muy cerca de los pedestales de las esculturas de culto del dios, su hermana Artemisa y su madre Leto, y de las mesas de ofrendas (Spawforth 2007: 145).

Asimismo, en 1813 se localizaron in situ dos tronos marmóreos flanqueando la puerta de entrada a la cella de un edificio sacro en la ciudad de Ramnunte (Ática, Grecia), que seguramente estarían sirviendo de asiento al personal encargado de la custodia del templo, en el ejercicio de esta faceta como vigías y guardianes del recinto (Spawforth 2007: 102).

Pero igualmente este elemento mobiliario está asociado a las figuras de culto, sirviendo entonces como soporte de las mismas. Las representaciones de deidades entronizadas forman parte de una tradición antiquísima presente en el Mediterráneo desde fechas muy tempranas y, de forma preferente, estos tronos parecen haber estado ligados en origen a figuras femeninas ( $\mathrm{La}$ Rocca 2007: 81; Richter 1966: 6), ya sean efigies de deidades, emperatrices divinizadas o matronas locales (Rodríguez 1979: 140). Especialmente numerosas son

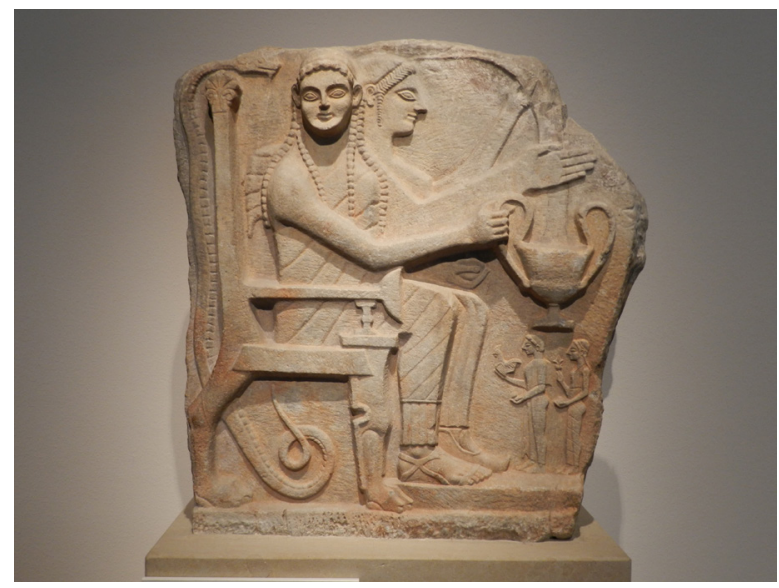

Figura 1. Relieve con héroes y devotos. Chrysafa, Esparta (Grecia). Mármol, hacia el 540 a.C. Altes Museum, Berlín.

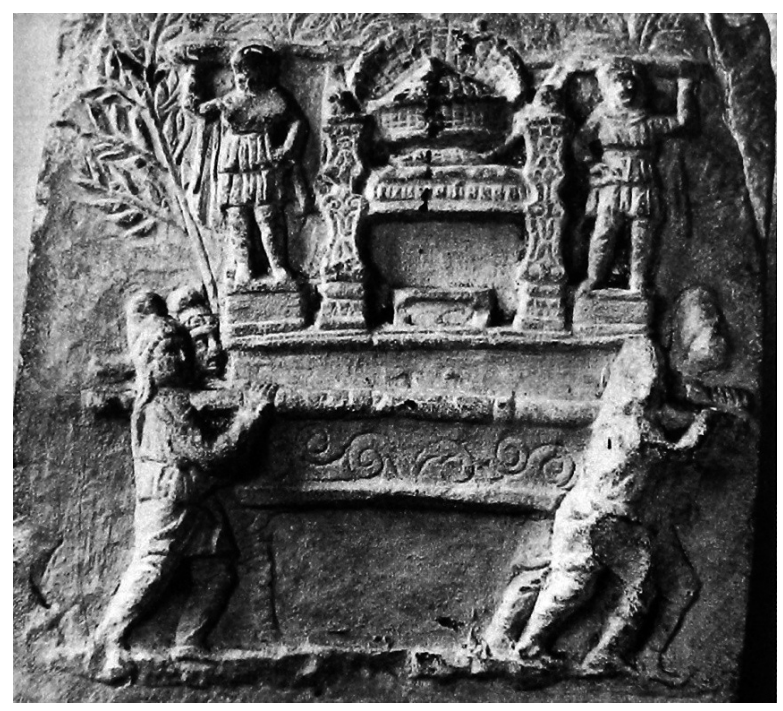

Figura 2. Altar votivo. Detalle del transporte sobre ferculum de un trono con la representación de la cista mística (exvuiae) de Magna Mater. Cambridge, Fitzwilliam Museum (La Rocca 2007: 88, fig. 11).

las representaciones de estas matronas en las zonas de Ática, Beocia, Rodas, Eleonte de Tracia, Costa Jónica, Magna Grecia y Sicilia, todas ellas datadas a finales del siglo V a.C. (Ruano 1990: 28). En nuestra península, previo al contacto itálico, ya existía esta tradición iconográfíca de matronas entronizadas (Baena 2011: 964) como observamos en los casos de la Dama de El Cigarralejo, Mula (Murcia) (Cuadrado 1995), o la Dama de Baza, un auténtico símbolo de la cultura ibérica, que tiene en estos modelos griegos de matronas sedentes 


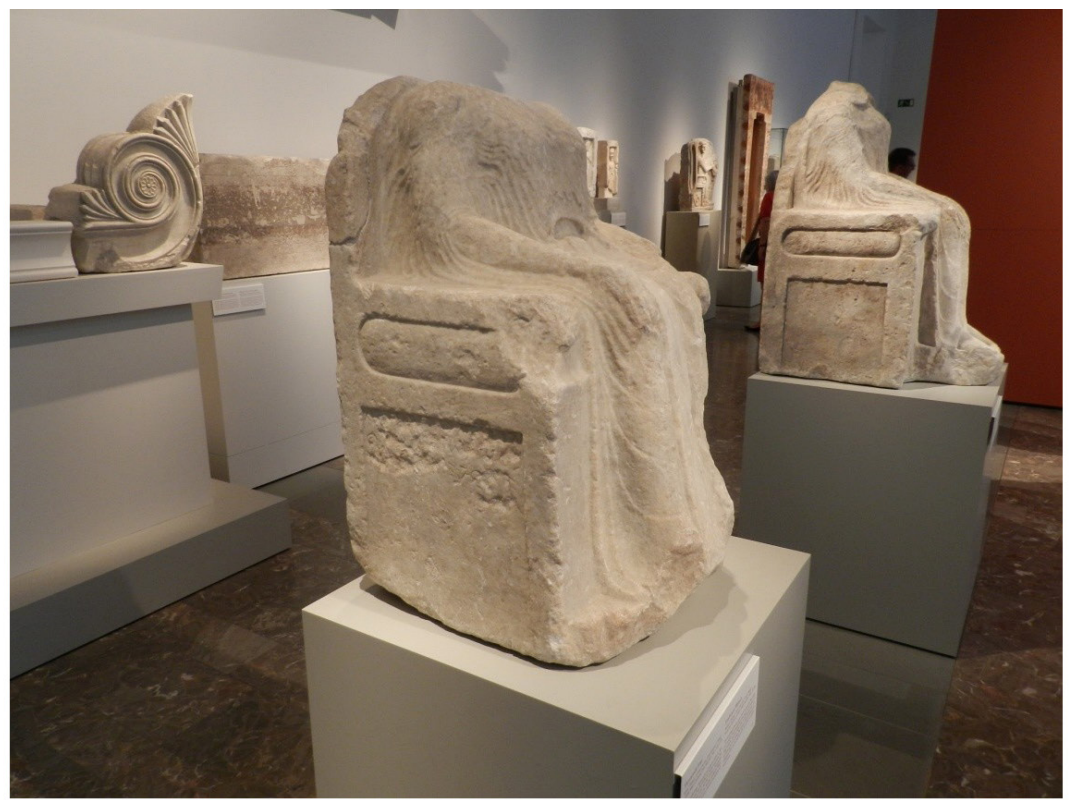

A
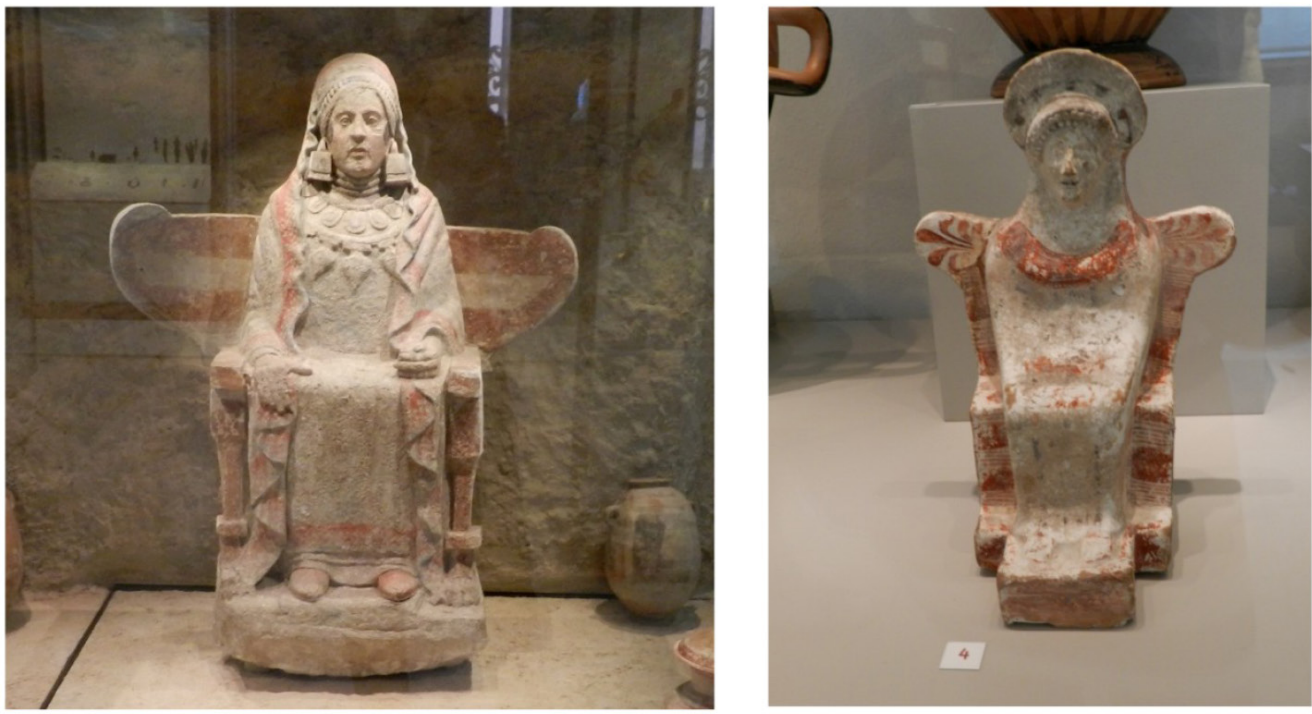

B

C

Figura 3. Damas entronizadas. A. Mileto (Turquía). Mármol, 540-520 a.C. Altes Museum, Berlín. B. Dama de Baza, piedra arenisca policromada, primera mitad del siglo IV a.C. Museo Arqueológico Nacional de España, Madrid. C. Atenea entronizada. Atenas (Grecia), terracota, hacia 500-480 a.C. Altes Museum, Berlín.

sus principales referentes y con los que guarda una gran similitud en morfología, sobre todo en el tipo de trono usado, con grandes alas laterales y patas con forma de garra de animal (fig. 3, B-C) (Bendala 2010).

En cualquier caso, ya sea como elemento indicativo de la celebración de sellisternia o como soporte de la escultura de culto de alguna divinidad, el thronos constituye un tipo de mobiliario que debemos asociar siempre a la élite social y a la esfera sacra en el mundo romano. En relación con ello baste mencionar la costumbre macedonia de introducir un trono en las tumbas de los altos dignatarios, hecho que reafirmaba su poder 
dejando patente el rol desempeñado en la sociedad en vida del difunto. En el contexto romano destaca el caso de César transmitido por Suetonio (Caes. 76, 1), en relación con la asignación de distintos honores, entre los que se encontraba un trono de oro en la curia y ante su tribunal, además de unas andas y una carroza en la procesión del circo

\section{TIPOLOGÍAS Y ORNAMENTACIÓN DE LOS THRONOI}

\subsection{Morfología}

El thronos en su acepción más universal, se presenta como un asiento monumental, con o sin ornamentación, aunque será muy frecuente encontrar en ellos una suntuosa decoración especialmente perceptible en la zona de sus patas. Otras veces se articularán de manera muy sencilla, a través de formas geométricas sin ningún tipo de adorno. Generalmente poseen respaldo y pueden o no acompañarse de escabel, aunque la presencia de este último es muy común y va casi siempre asociada a este tipo de mobiliario (Richter 1966: 14 y 99). Otro elemento presente habitualmente en estos soportes es el cojín o manto con el que suele cubrirse la zona del asiento (fig. 4).

En origen se encontraban elaborados en madera y ornamentados con pintura y ricos materiales, como el ébano, el marfil o metales preciosos (Richter 1966: 5, 14 y 125). Pero el carácter vulnerable y perecedero de la madera no encaja bien con las pretensiones con las que se realizan este tipo de asientos, siendo pronto sustituida por el mármol, un material que permite dotar al mueble de ese halo eterno y perdurable que sólo la piedra proporciona (Kottaridou 2006: 160).

De forma general todos los thronoi comparten una serie de características que consideramos comunes, en la mayor parte de los casos, en este tipo de mobiliario. A grandes rasgos y a nivel morfológico, existen dos formas habituales de composición que vamos a observar en las patas de estos elementos, al ser estas, como ya hemos señalado, la zona más característica de los mismos. En este sentido conviene señalar que serán tratados en este trabajo los thronoi de la tipología III de G. Richter (Thrones with rectangular legs), ya que son el modelo más difundido y empleado en el periodo romano. Se trata de una creación propiamente griega, presente en distintas representaciones desde el segundo cuarto del siglo VI a.C. Este tipo de asientos sufrirá un progresivo cambio a partir del siglo IV a.C., cuando comienza a detectarse una mayor carga ornamental.

Las patas suelen articularse a través de tres tipos de piezas distintas: formando el remate superior e inferior, encontramos generalmente o bien una moldura de tipo geométrico, compuesta por diferentes niveles de listeles $\mathrm{u}$ otro tipo de elementos de formas rectilíneas y/o curvas (fig. 6, Esquemas I y II, A), o igualmente es frecuente encontrar un capitel eólico (sobre todo en el remate de la zona superior); a continuación hallamos una pieza formada por elementos cóncavos en sus extremos que va a configurar siempre la característica forma del thronos
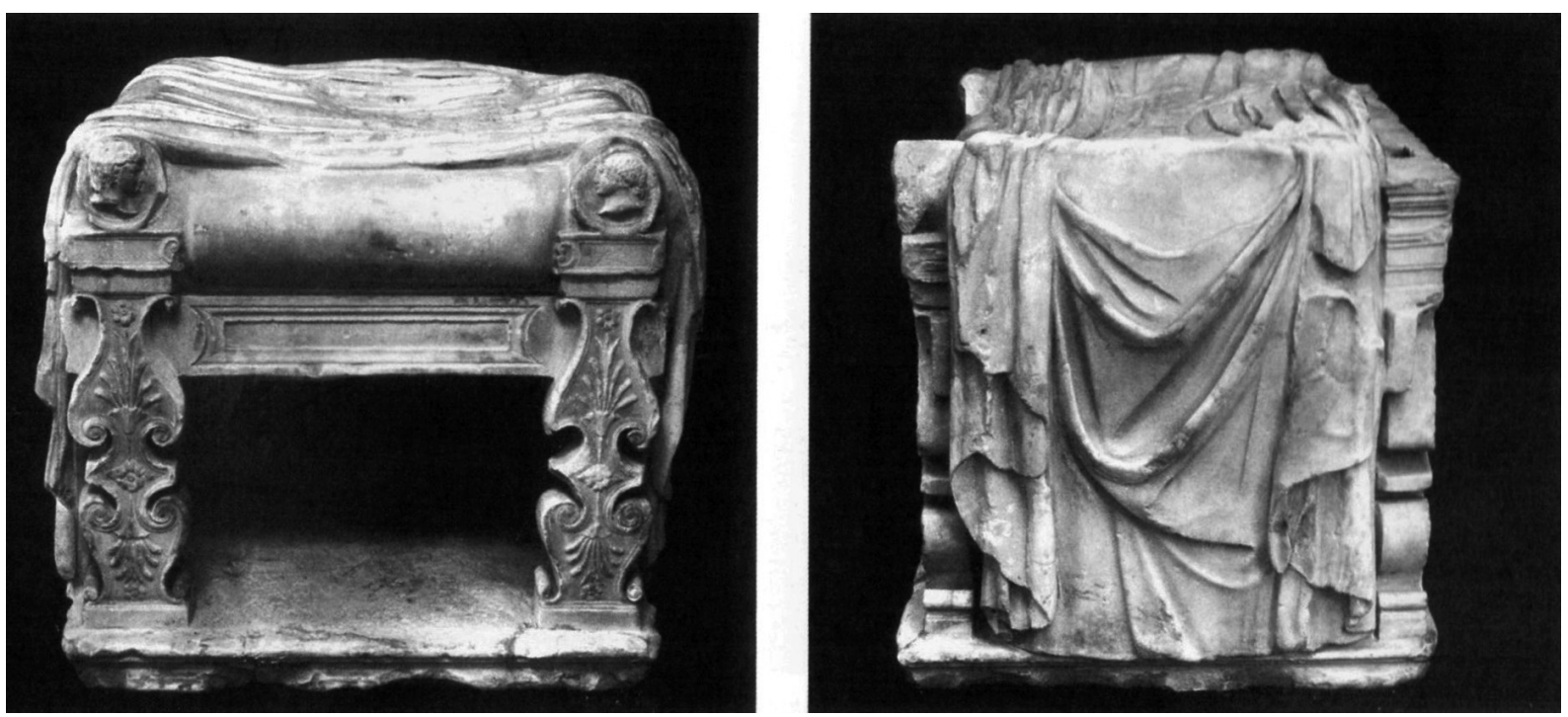

Figura 4. Thronos marmóreo. Gliptoteca de Mónaco, Baviera (La Rocca 2007: 99, fig. 20-21). 

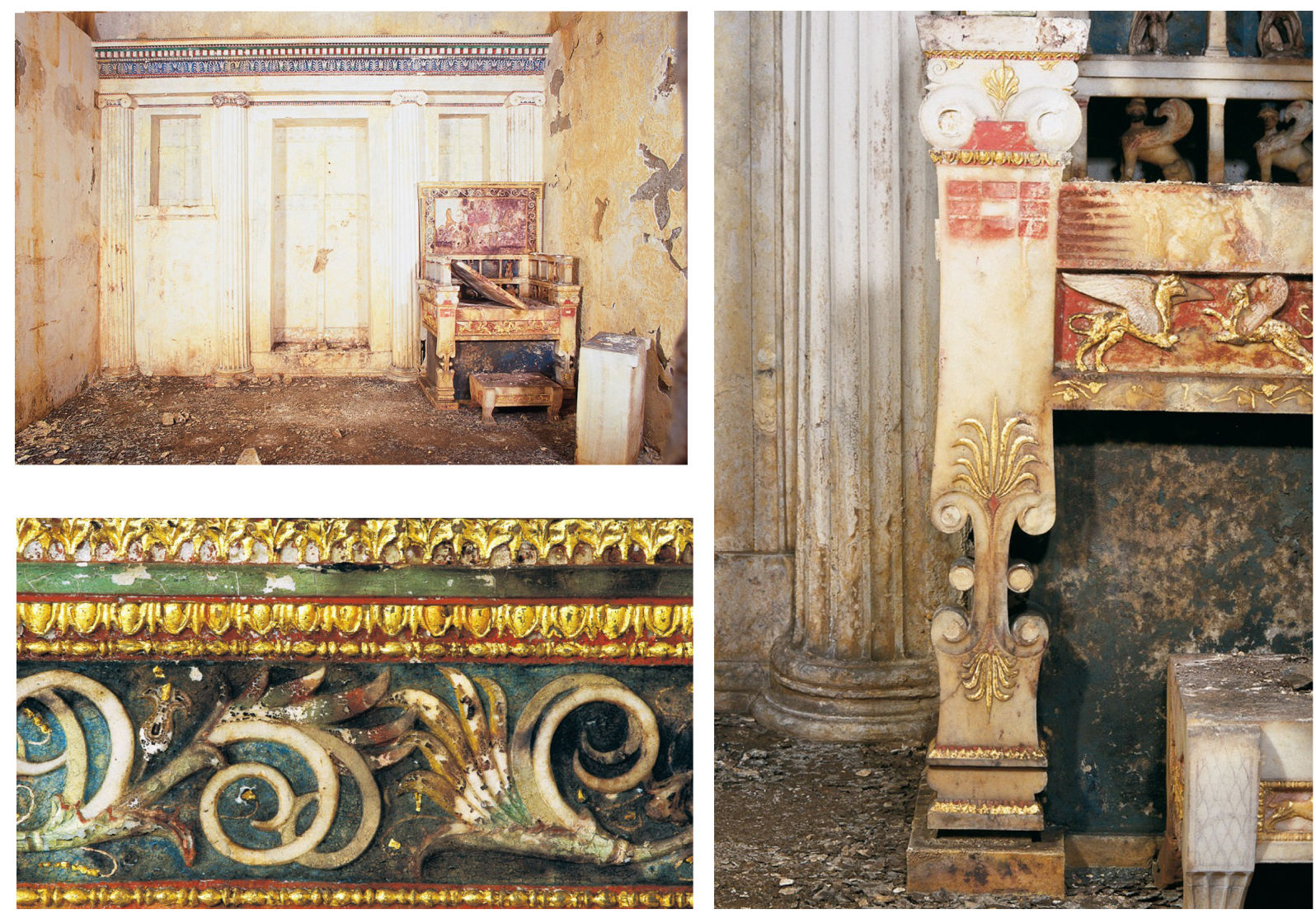

Figura 5. Izquierda, arriba: Interior de la tumba y thronos funerario de la reina Eurydice (Vergina, Grecia). Izquierda, abajo: Detalle del marco del respaldo del thronos decorado con motivos vegetales. Derecha: Detalle de la pata del thronos (Kottaridou 2006: pl. 59, 2; 61, 4 y 60, 4).

(fig. 6, Esquemas I y II, B). Finalmente, un tercer componente que unirá las zonas superior e inferior de las patas funcionando a modo de núcleo o eje central de la composición. Esta moldura puede adoptar dos aspectos distintos: o bien se presenta como una moldura articulada a través de elementos geométricos, especialmente listeles, cavetos y boceles de distintos grosores (fig. 6, Esquema I, C), o se configura por medio de un par de elementos cóncavos y alargados cuyos extremos se encuentran decorados con volutas (fig. 6, Esquema II, C).

Otra tipología distinta es la de thronoi lisos, los cuales suelen adoptar las formas anteriormente mencionadas pero sin contener ningún tipo de decoración interior. En otros casos, presentan unas estructuras muy sencillas, a base de líneas rectas o con forma de cubo, con un aspecto rígido y pesado. En este tipo podemos encontrar igualmente las dos variantes, con o sin respaldo y escabel, aunque a veces, la presencia de este modelo de thronos será poco advertida, ya que la elección de esta tipología da lugar a un mayor protagonismo del personaje representado, puesto que la inexistencia de cualquier huella ornamental en los soportes provoca que toda la atención recaiga en la figura principal. Además, muchos de estos tronos, especialmente en los casos de las figuras femeninas, llegan en ocasiones a ser casi invisibles, pues quedan tapados por los amplios y largos ropajes de las efigies. Esta tipología la encontramos habitualmente en las figuras marmóreas de distintas divinidades tales como Júpiter, Serapis, Ceres, Fortuna o Cibeles, cuyas representaciones entronizadas suelen ser muy frecuentes (fig. 7) e igualmente, parecen ser el soporte de muchas emperatrices divinizadas. Debido a lo numeroso de los casos, recordaremos únicamente algunos ejemplos, tales como la figura de Ceres sedente conservada en el Museo Nacional de Arte Romano (Mérida, Badajoz) ( $n^{\circ}$ de inventario CE00562), correspondiente al s. I d.C. y procedente del teatro de la ciudad romana; una figura femenina entronizada correspondiente a la etapa augustea procedente de Villa de Vale de Aguieiro, (Beja, Portugal) conservada en el 
Museo de Évora ( ${ }^{\circ}$ de inventario ME 1707) y considerada como posible representación de Juno, Ceres, Fortuna o Cibeles; la figura de Livia representada como Fortuna procedente de Iponuba (Baena, Córdoba), conservada actualmente en el Museo Arqueológico Nacional (Madrid, España) datada en los años 20-40 d.C. o la figura acéfala de Serapis entronizado conservada en el Museo Nazionale di Arte Romano, Palazzo Altemps (Roma, Italia) ( $n^{\circ}$ de inventario 2004536), datada en el siglo II d.C.

\subsection{Ornamentación}

Los elementos decorativos presentes en estos soportes y su grado de elaboración nos ayudarán a definir el carácter de la figura representada, además de aportarnos información sobre la vida del mismo, ya que en ocasiones, narran pasajes o hechos vinculados con experiencias de la figura. El hecho de que la superficie disponible para decorar en ese tipo de elementos sea relativamente reducida obliga, en cierta medida,

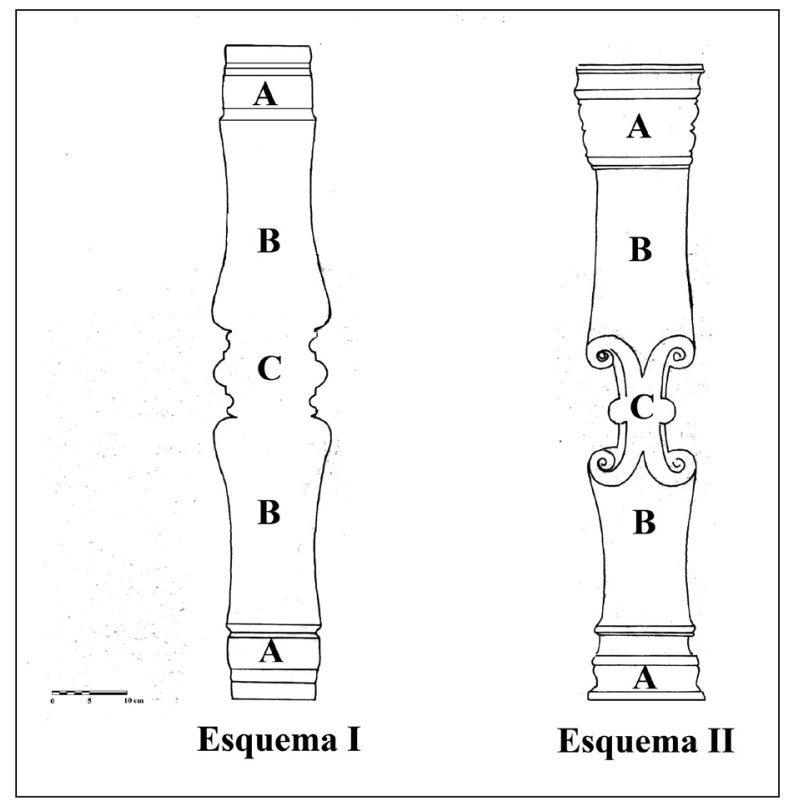

Figura 6. Esquemas básicos de patas de tronos (dibujo Ana Portillo a partir de un modelo de C. Márquez, 2004: 343, fig.11).
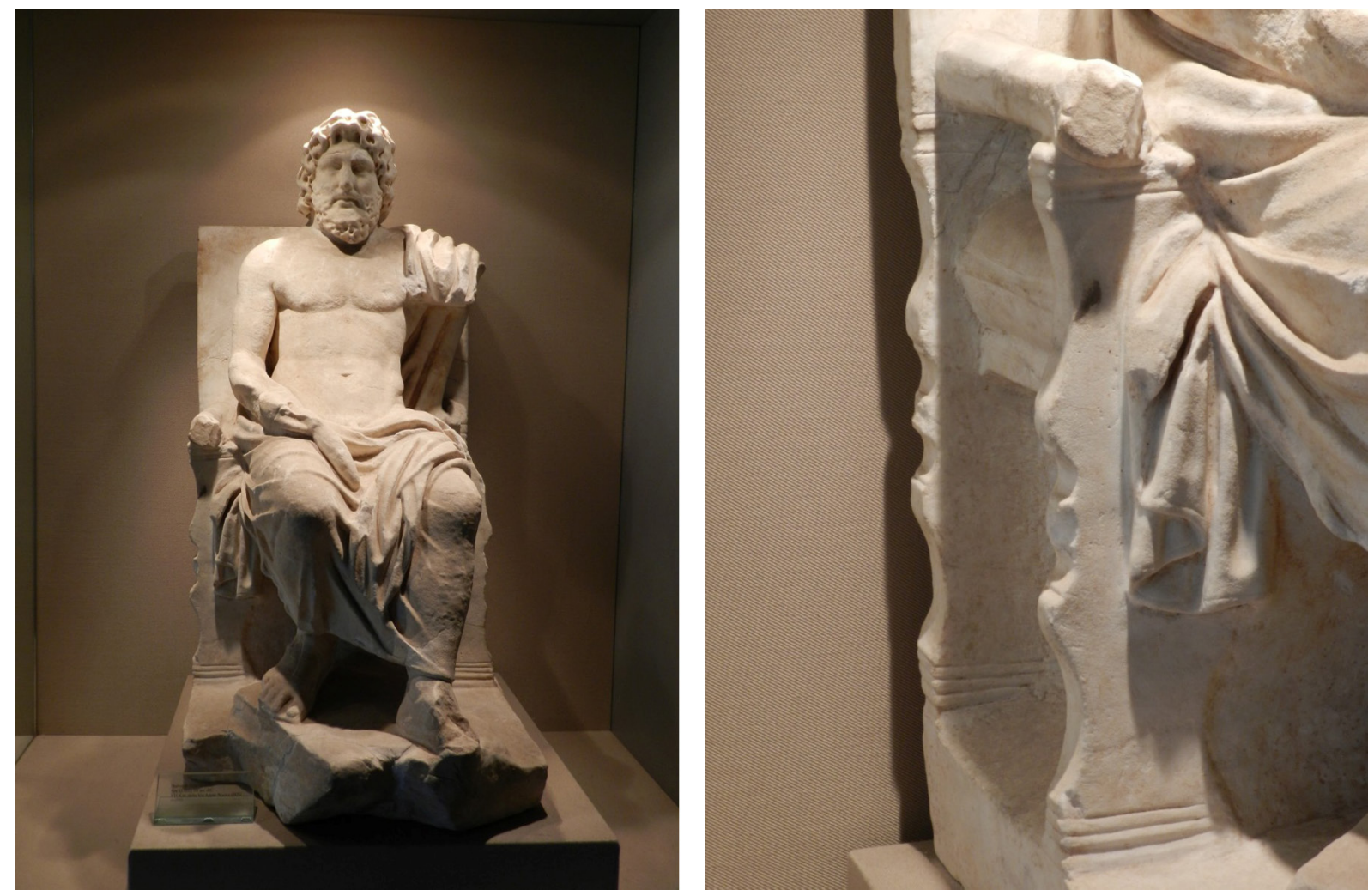

Figura 7. Zeus entronizado. Finales del siglo II-principios del III d.C. Recuperada en 1929 en el km 7 de la Via Appia Nuova. Villa dei Quintilli, Roma. 
a seleccionar motivos ornamentales muy concretos, simbólicos, fácilmente reconocibles y cargados de significado. Contamos con numerosas referencias a estos thronoi en la Antigüedad a través de la literatura clásica, como los testimonios hallados en la Biblia, (Libro I de los Reyes $(\mathrm{X}, 18)$ en referencia al trono de Salomón; Daniel (V, 20), haciendo alusión al trono de Nabucodonosor; Hebreos (I, 8), sobre el trono de Dios) o en clásicos como la Odisea donde se nos habla del trono de los dioses en las rapsodias I, VII, XIX, XX, XXI, y XXIII. También Pausanias (II, 27, 2) nos habla del trono de Asklepios o del trono de Apolo en Amiclea (III, 18, 9), donde, en ocasiones, se describen de forma muy precisa, como el caso paradigmático del thronos de Zeus en Olimpia transmitido por Pausanias (V, 11, 1-7), considerado como el modelo ideal que tomarán los emperadores romanos para sus representaciones como dios-gobernante (Lapatin 2014: 55).

Habitualmente los thronoi van a decorarse por medio de motivos vegetales o figurativos o una combinación de ambos. En casi todos los casos conocidos hallamos el empleo de un lenguaje vegetal en el que va a destacar, de forma clara y evidente, la presencia de la palmeta con un número de brazos impares como motivo decorativo principal, con el que normalmente se va a establecer el eje de simetría de la composición. La existencia de estas palmas se encuentra claramente ligada al significado religioso y ritual de esta planta en la Antigüedad, sirviendo por tanto, como un elemento de reconocimiento y ligazón de estos soportes con la sacralidad. La propia etimología de la palma, phoenix dactylifera, hace referencia a este entorno sagrado, ya que el término griego phoenix viene a coincidir con el nombre de la púrpura, un color muy vinculado a la esfera religiosa, con el que solían representar las prendas textiles que portaban los dioses en el mundo greco-romano (Portal 2016: 119-120). El término también corresponde al nombre de la mítica ave que resurge de entre sus cenizas tras haber completado la regeneración del cosmos.

Pero el valor simbólico de la palma es amplio y complejo, representando, cuando se reproduce entera, el árbol de la vida por excelencia desde época sumeria. En el contexto greco-romano debemos vincularla a la figura de Apolo, en cuanto que según la mitología homérica, el dios nació junto con su hermana Artemisa, a la sombra de una palmera. Igualmente debemos recordar el episodio que narra Ovidio (Fast., III), del sueño de Rea Silvia en el cual se hace referencia a dos palmas, entre las que una, la más grande y vigorosa, profetizaba la grandeza de Roma. Por último, conviene también destacar que griegos y romanos, así como los hebreos, consideraban a las coronas o ramas de palma símbolos de la victoria, un significado que ha perdurado en el tiempo, siendo usado actualmente en la iconografía cristiana (Caneva 2010: 107-108). Esta palma se va a combinar con otros tantos motivos vegetales como roleos, cálices y rosetas, todos ellos forman parte de un esquema decorativo que nos habla de la regeneración (especialmente a través de los roleos) y los ciclos de la vida, una temática muy presente en toda la plástica augustea. Augusto retoma y potencia este lenguaje ornamental a través del cual transmite su ideario político, entendiendo la naturaleza como un medio que todo lo invade, pero se trata de una naturaleza ordenada, racional y controlada por el hombre, que podemos traducir como una exaltación simbólica del nuevo Estado (Zanker 2008).

Por otro lado, resulta igualmente frecuente encontrar decoraciones compuestas por distintas figuras, normalmente de personajes mitológicos o alegóricos, que aportan un gran contenido y significación a la obra. La presencia de esfinges, grifos o Gorgonas proporcionan un sentido apotropaico, actuando como custodios o guardianes (Izquierdo y Le Meaux 2003, Silva 2012: 45 y 49). Pero también suelen aparecer otro tipo de figuraciones tales como las victorias aladas, animales $\mathrm{u}$ objetos rituales (fig. 8), que nos hablarán en estos casos del carácter triunfante o sagrado del personaje que ocupa el thronos.

Un ejemplo excepcional por la calidad técnica del trabajo, el repertorio iconográfico y su buen grado de conservación, es el thronos del emperador Calígula localizado en Nemi (Italia). La escultura, recuperada por la Guardia de Finanzas en el año 2011, se presenta como una representación del emperador divinizado y sedente en un thronos con alto respaldo (Ghini 2014) (fig. 9). El personaje entronizado aparece con largo manto que cubre las piernas dejando libre la zona del torso, para apoyarse de nuevo sobre el hombro izquierdo. En este tipo de representaciones, el brazo derecho suele recaer sobre la pierna sosteniendo un objeto (globo, volumen, etc.) y el izquierdo en cambio, aparece normalmente alzado agarrando un cetro. Este modelo iconográfico se inserta en una serie muy usada por los emperadores julio-claudios (fig. 10), especialmente tendentes a representarse según este prototipo con un claro mensaje propagandístico, cuyo origen se encuentra en la escultura que Fidias realizara de Zeus para su templo en la ciudad de Olimpia.

La decoración del thronos de Nemi se ha basado en elementos arquitectónicos y figurativos. El respaldo se 

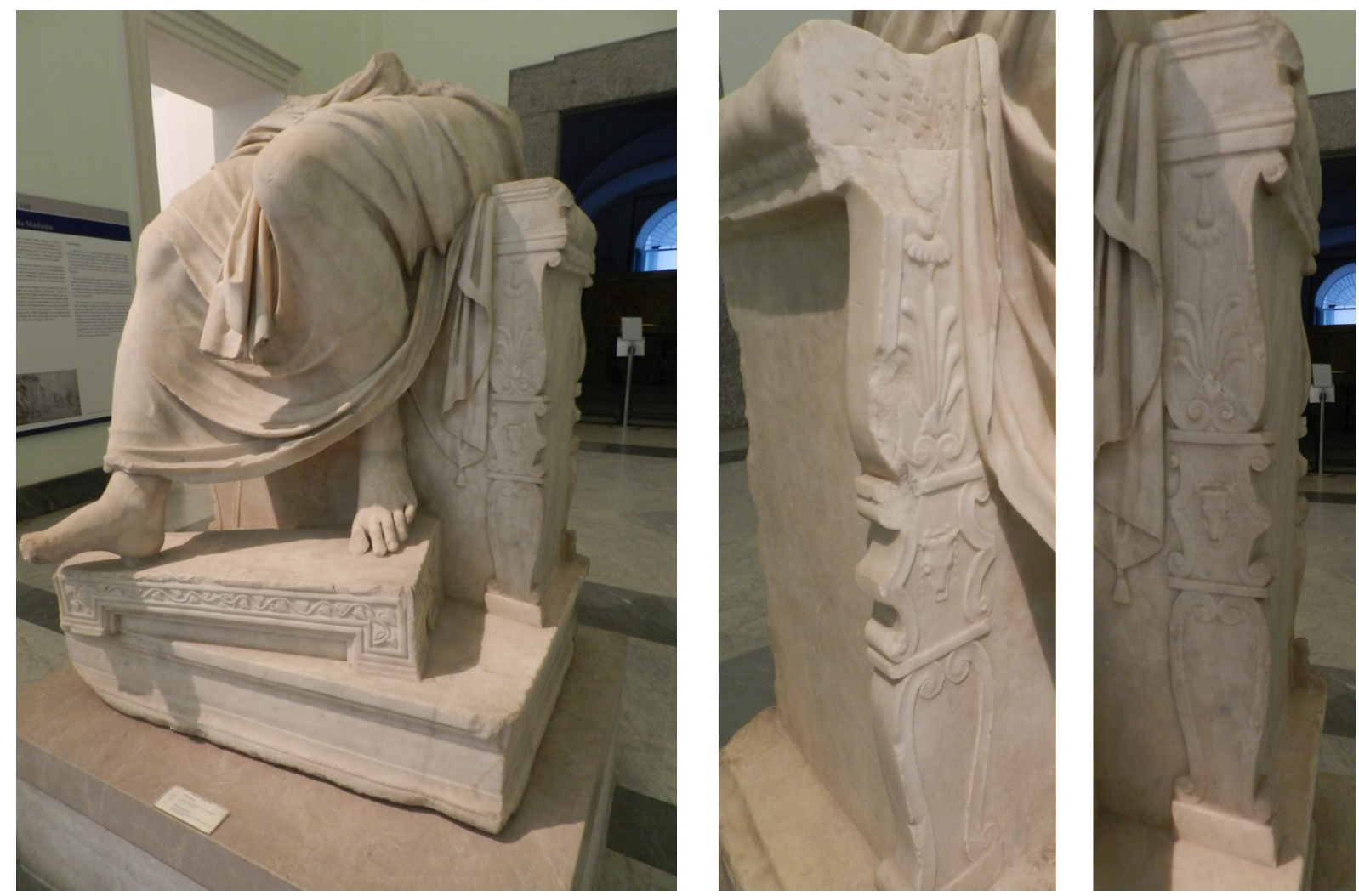

Figura 8. Júpiter entronizado. Copia de la primera mitad del siglo III d.C. de un original griego del siglo III-I a.C. (Museo Arqueológico Nacional de Nápoles).

compone de un frontón triangular flanqueado por dos pilastras corintias de hojas lisas; las patas en cambio, presentan una mayor ornamentación, presididas por un capitel eólico que da paso a una victoria alada que sostiene un urceus en su mano derecha. Le sigue en orden descendente una cabeza de Gorgona que aparece rodeada por cuatro volutas y finalmente, como último personaje, aparece una figura femenina alada, desnuda hasta las caderas, con los brazos extendidos, que parece surgir de entre olas. La primera efigie hace alusión directa al triunfo, quizás en relación a la anexión de la provincia de Mauritania, uno de los grandes logros militares de este emperador. En este caso, la figura de la Victoria porta un elemento ritual, el urceus o jarrita para realizar libaciones, un objeto que envuelve de sacralidad la escena creando un marco religioso en el que Calígula se sentiría muy cómodo, ya que sabemos de su gusto por aparecer públicamente ataviado como un dios o la erección de templos a su persona en vida (dos en Roma y uno en Mileto) y de recibir otros tantos honores como divinidad viviente (Suet., Calig. IV, 22). $\mathrm{Si}$ bien resultan ser más frecuentes y numerosas otro tipo de representaciones de Victoria en el mundo romano, vinculadas sobre todo a la concesión del triunfo a algún personaje, la iconografía de Victoria con este tipo de objetos ligados a la ritualidad (como coronas, cintas, jarras, etc.), procede de un modelo helenístico muy reproducido en la Roma altoimperial, de los que conservamos algunos relieves tales como el ejemplar custodiado en el Museo del Louvre (París) o el conservado en el British Museum (Londres). En ambos casos la diosa sujeta un urceus en sus manos y se dispone a realizar una libación frente a la figura de Apolo citaredo (Olteanu 2011, Rodríguez 2013: 107-109).

La Gorgona es un claro símbolo de poder en el arte griego desde el siglo VII a.C. (Lapatin 2014: 56-57), asumida y adoptada por la iconografía imperial romana, siendo usada de forma casi constante en distintos ámbitos. Además esta figura funciona a modo de amuleto, ahuyentando el mal de quienes a ella recurren.

En nuestra opinión la última figura podría estar representando nuevamente a Victoria, en este caso ligada a las contiendas marítimas, quizás escenificando una suerte de acto profético y premonitorio en virtud del 


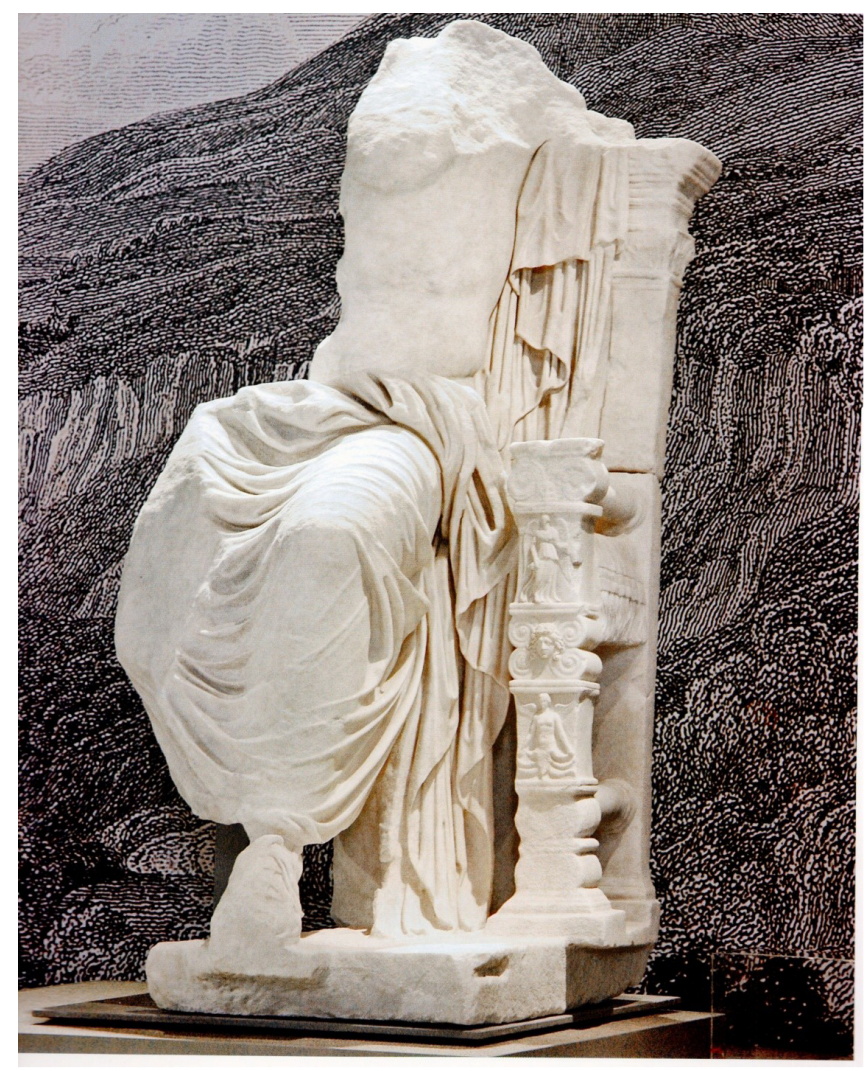

$\mathbf{A}$

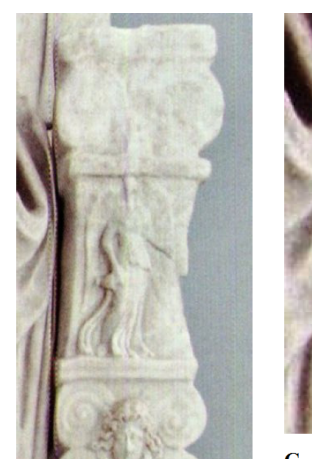

C

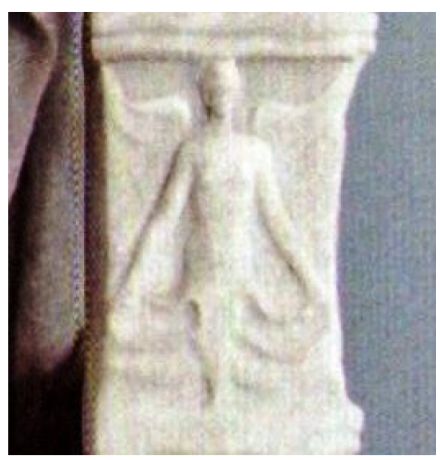

D
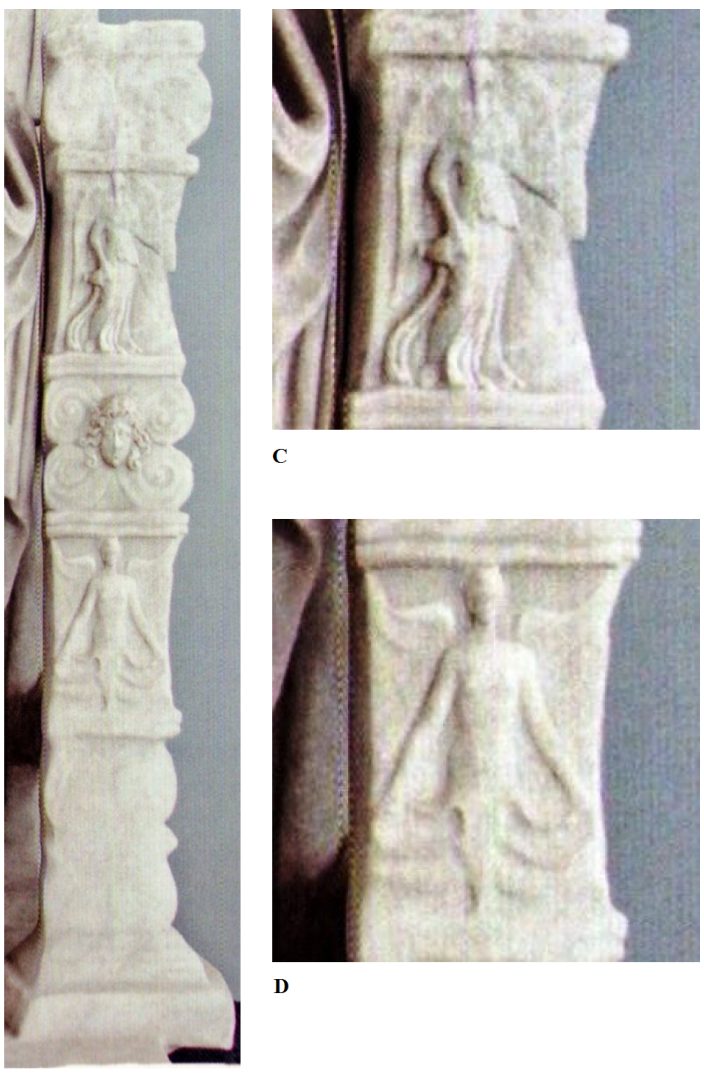

Figura. 9. A. Escultura del emperador Calígula entronizado procedente de Nemi-Velletri. Siglo I d.C., mármol blanco. B, C y D. Detalle de la pata y la figuración del thronos. Museo delle Navi Romane di Nemi (Ghini et alii 2014: 107).

triunfo de las tropas romanas contra la isla de Britania. Victoria encarna la idea del triunfo en sí misma y como vástago del dios de la guerra, fue asimilada al poder de los ejércitos y éxitos militares tanto terrestres como marítimos (Rodríguez 2013: 110). Creemos por tanto, que esta podría ser la justificación de su doble presencia en la decoración del thronos de Calígula: la primera, como testimonio del triunfo conseguido, escenificando o disponiéndose a llevar a cabo un acto de agradecimiento a una divinidad a través, probablemente, de una libación. La segunda manifestaría el inminente éxito romano ante las tropas britanas, una contienda muy vinculada al mar al tratarse de la conquista de una isla.

Otro de los aspectos fundamentales en la decoración de este tipo de soportes será, sin duda, el color. En la literatura clásica encontramos a menudo adjetivos aplicados a los tronos, tales como reluciente (Hom., Il., XVIII, 422), brillante (Hom., Od. V, 86), dorados o con incrustaciones de oro y plata (Pindar., Pyth. Odes, IV, 260; Hom., Od., VII, 162; Suet., Caes, 76,1), colorido (Paus.,
$\mathrm{V}, 11,1-7)$, etc. Este hecho nos muestra la suntuosidad de la que hacía gala este tipo de elementos. Un ejemplo claro de esta rica ornamentación lo hallamos en el thronos funerario de la tumba de la reina Eurydice en Vergina, Grecia (344/3 a. C.). Se trata de un asiento elaborado en mármol de Paros, dorado y policromado (fig. 5). En él encontramos toda una serie de elementos vegetales, donde la palma vuelve a ser la protagonista, además de un repertorio figurativo donde reconocemos esfinges, leones y grifos en los relieves y en pequeñas esculturas, además de un panel pictórico que cubre el respaldo con la representación de una cuadriga guiada por Hades y Perséfone. Observamos en esta pieza cómo la pintura no se emplea con una intención de mímesis de la naturaleza, sino con un carácter simbólico (palmas doradas sobre fondos azules, etc.). Algunas zonas del thronos se han dejado intencionadamente en el color blanco reluciente del mármol (volutas del capitel eólico $\mathrm{y}$ fondo de las patas, marco y figuras de la zona inferior del respaldo, etc.) y otras tantas han recibido color y 

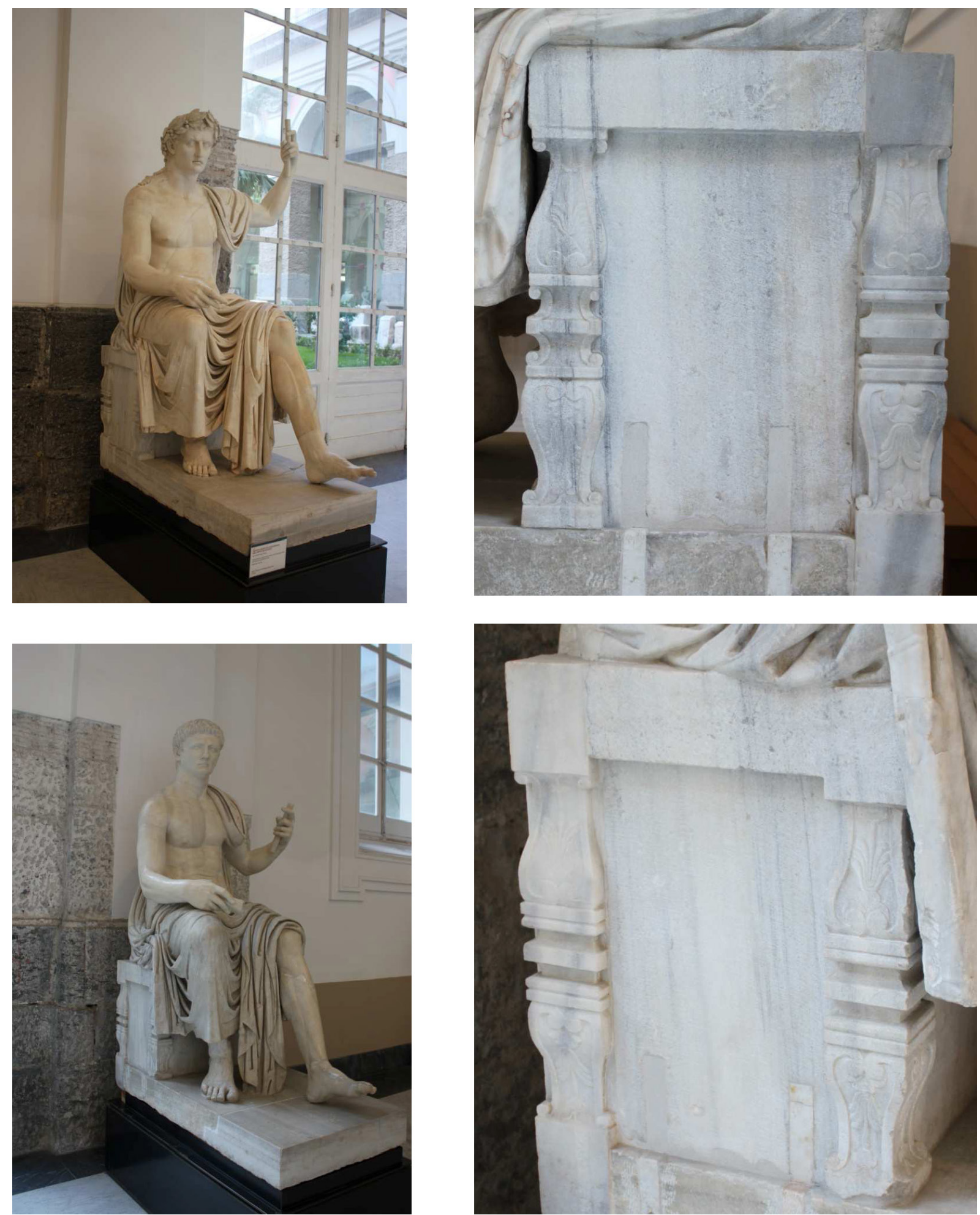

Figura 10. Izquierda: Esculturas de Divus Augustus (arriba) y Claudio (abajo) entronizados procedentes del Augusteum de Herculano. Mármol blanco, primera mitad del siglo I d.C. Derecha: Detalle de los thronoi de las figuras (Museo Arqueológico Nacional de Nápoles). 
dorado, con la intención de dar la sensación de tratarse de una obra crisoelefantina (Kottaridou 2006: 162). En el arte de la Grecia clásica las obras elaboradas en oro y marfil constituían el summum de la suntuosidad, expresión material máxima de la riqueza y elegancia, por ello el honor de recibir una escultura realizada en estas materias era concedido únicamente a los dioses. Esta es la idea que subyace en el diseño de piezas como el thronos de la reina Eurydice, donde el delicado marfil se ha sustituido por el duro mármol, dotando así a la obra de ese carácter eterno, buscado especialmente en las piezas de carácter funerario. Estos serán los modelos asimilados por Roma, reproduciendo en sus obras estos mismos esquemas decorativos. Aunque si bien es cierto que, por el momento, no contamos con numerosas evidencias de tronos marmóreos de época romana que conserven huellas de color, debemos suponer que todas estas piezas se presentarían originalmente policromadas y/o doradas.

\section{THRONOI HISPANIARUM}

En el territorio hispano contamos con varios ejemplos de este tipo de elementos, algunos de ellos de carácter inédito hasta el momento, hallados, en su mayoría, en el entorno de foros y asociados al interior de templos monumentales. Así, tanto los fragmentos hallados en la calle Morería, un fragmento procedente de la calle Cruz Conde (fig. 11, D), como el perteneciente al área del templo de la calle Claudio Marcelo de la ciudad de Córdoba, son piezas de carácter inédito que presentamos por primera vez en este trabajo como aportaciones al estudio de esta tipología escultórica. Todas ellas fueron analizadas en el marco de las Tesis Doctorales de las Dras. M. I. Gutiérrez Deza (templo calle Claudio Marcelo) y Ana Portillo (Fragmentos calle Morería y fragmento c/ Cruz Conde (fig. 11, D).

Aun así, debemos admitir que se trata de piezas poco conocidas, ya que ciertamente, son muy escasos los testimonios documentados. Con el objetivo de proporcionar una sistematización del tema de estudio, dividiremos el área geográfica por provincias.

\subsection{Baetica}

\subsubsection{Colonia Patricia Corduba}

En la capital de la provincia contamos con diversos fragmentos de thronoi localizados en distintas zonas de la ciudad. Algunos de ellos fueron estudiados por C. Márquez (1997) en la década de 1990 (fig. 11, A, B, C y E), quien los relaciona con el interior de la cella del templo de la calle Morería, en el forum novum de la ciudad (Márquez 2004: 343). Se trata de un conjunto de fragmentos que configurarían dos patas de tronos distintas. Se encuentran elaborados en un mármol blanco de grano muy fino, destacando en ellos el empleo de un lenguaje vegetal de gran naturalidad que llevó a Márquez a relacionar estas piezas con el Ara Pacis Augustae, datándolas por su estilo y talla, en el periodo tiberiano o claudio (Márquez 1997: 73; 2004: 343; 2009: 115, figs. 5-6).

Estas piezas habían sido puestas al descubierto previamente por Samuel de los Santos Gener a mediados del siglo XX, siendo halladas durante los trabajos arqueológicos llevados a cabo por el arqueólogo en la calle Cruz Conde (Santos 1955: 78, fig. 32). En esta intervención se extrajo un amplio conjunto de materiales que, en nuestra opinión y a consecuencia de la disparidad de sus características formales y por la gran cantidad de piezas, procederían en parte de los dos centros públicos más cercanos, el foro colonial y el forum novum (Márquez 1998b). Este presunto depósito reúne numerosos fragmentos tanto arquitectónicos como escultóricos, presentando estilos, calidades y materiales en ocasiones muy distintos que nos llevan a plantear, a modo de hipótesis, la posibilidad de que formasen parte de la evolución continuada de uno o varios espacios públicos de la ciudad.

Además de la procedencia, el estilo y el tipo de material empleado, otro dato importante que nos ayuda a relacionar estos fragmentos serán las dimensiones. Las piezas halladas en el solar $n^{\circ} 16$ de la calle Cruz Conde comparten unas medidas similares en la profundidad de las placas, que oscilan entre 4 y $4,5 \mathrm{~cm}$. A esta serie debemos sumar un nuevo fragmento documentado en 2012, en el desarrollo de un estudio de materiales en los fondos del Museo Arqueológico y Etnológico de Córdoba (fig. 11, D). Se trata de una pieza que comparte las mismas características formales, materiales, procedencia y formato con las anteriormente citadas estudiadas por Márquez. En esta ocasión observamos una palmeta de nueve brazos que emerge de un cáliz abierto. El diseño de este fragmento se ajusta bien a uno de los hipotéticos modelos de patas de tronos elaborados por Márquez en su estudio (fig. 11, E, derecha), un hecho que reforzaría la veracidad en la existencia de este esquema.

Por otro lado, contamos con otros tantos fragmentos hallados en la calle Morería (Córdoba) que determinarían otro trono distinto, en este caso de mayor tamaño. En concreto hemos documentado tres piezas de 


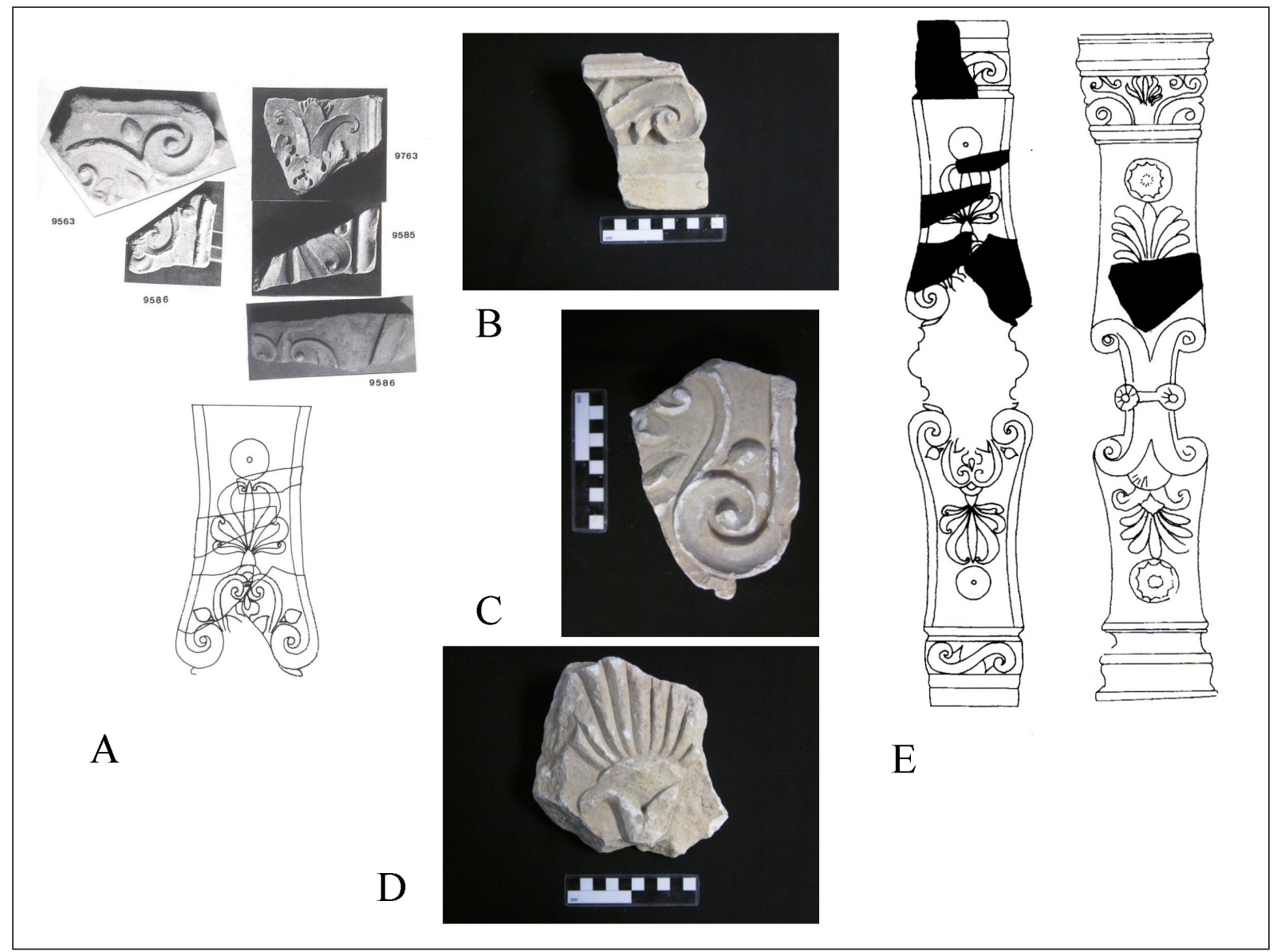

Figura 11. A-D: Fragmentos de tronos marmóreos procedentes de la calle Cruz Conde, Córdoba. ((A) Márquez 1997: 85, lám. 2 y 87, fig. 5; (B-D) Portillo 2016b: tomo II, 527, lám. nº 1; 529, lám. no 2; 533, lám. nº 5). E: Reconstrucción de dos modelos de patas de tronos a partir de los fragmentos procedentes de la calle Cruz Conde, Córdoba (Márquez 2004: 343, fig.11).

diferentes zonas del trono: dos corresponderían a una pata, en concreto a una voluta de un capitel eólico, otra al eje central de la composición de uno de los extremos largos de la pata, formado por una palmeta y una tercera, al respaldo. Todas ellas reúnen idénticas particularidades, que nos han llevado a datarlas en la primera mitad del siglo I d.C.: formas definidas, carnosas, con perfiles bien delimitados, creando dos planos de profundidad diferenciados con zonas de contraste especialmente perceptibles en algunos casos (figs. 12 y 13).

En relación con el fragmento de capitel eólico, únicamente conservamos una de sus dos volutas, cuya cara posterior se encuentra lisa y pulida; la anterior presenta una acusada profundidad muy evidente en el roleo de la misma, realzando y destacando la moldura. El mármol se encuentra en estado de deshidratación y si a ello sumamos que conserva una capa superficial negruzca, el resultado es un más que posible contacto con fuego, bien sea por motivo de algún incendio o por hallarse en las cercanías de un calerín, en cuyos hornos se reaprovechaba el material marmóreo transformándose en cal. El espesor de esta pieza, $10,5 \mathrm{~cm}$, nos habla de un thronos de gran empaque, seguramente destinado a una deidad principal, posiblemente el Divus Augustus, a quien estaba dedicado el templo que presidía el forum novum (Márquez 2004; Ventura 2007; Peña et alii 2011; Porti1lo 2014-15; 2015a, 2015b, 2015c, 2016).

Otra de las piezas de este gran thronos conserva parte del que sería muy probablemente el motivo decorativo principal de la pata. Se trata de un fragmento de mármol blanco que presenta el mismo estado de conservación que el anterior, deshidratación de la materia, textura arenosa con tendencia a desintegrarse y la misma capa oscura en la superficie. Una palmeta de siete brazos cóncavos surge de un cáliz abierto cuyos extremos se enroscan formando pequeños roleos laterales. El grosor de la 


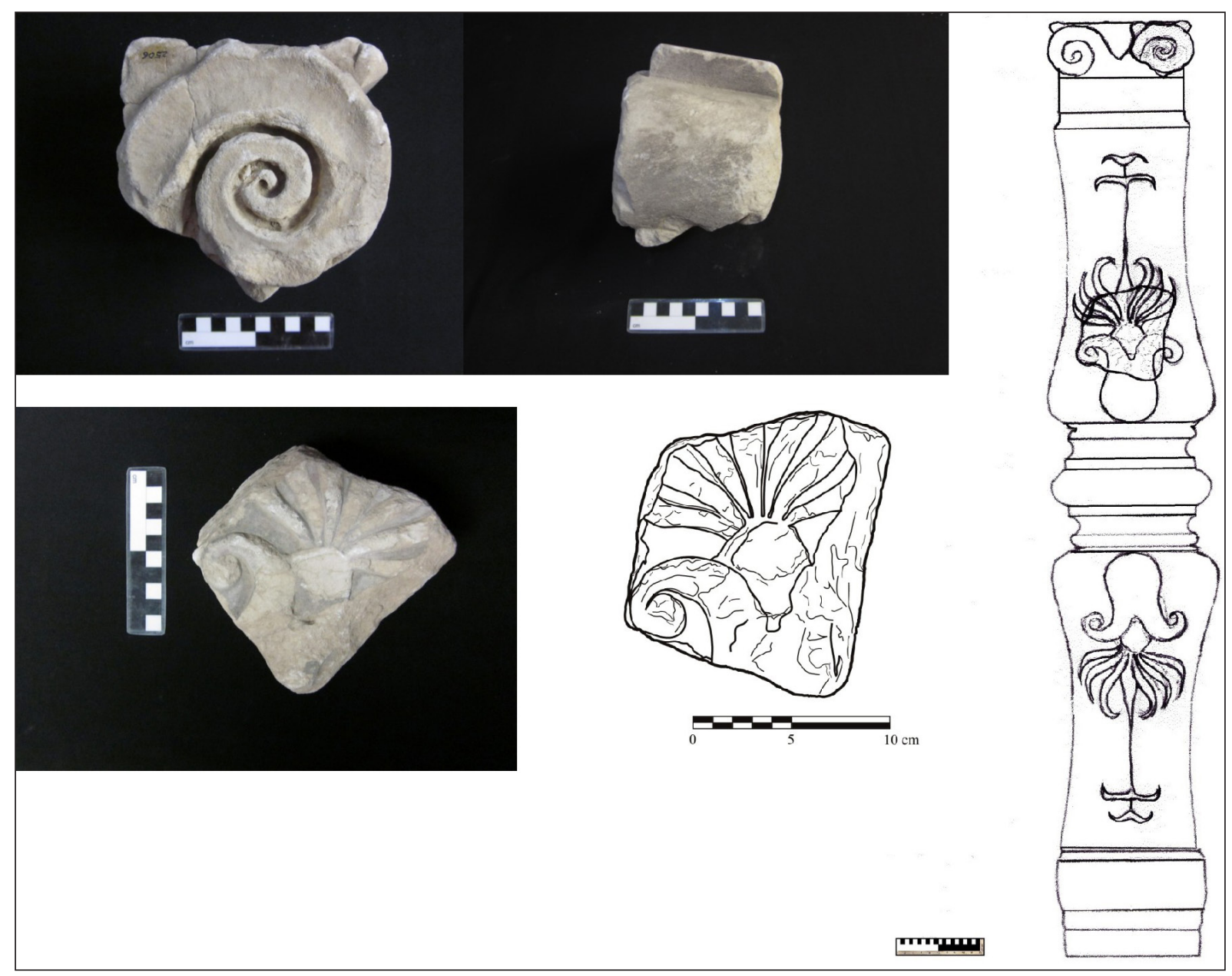

Figura 12. Fragmentos de tronos marmóreos procedentes de la calle Morería, Córdoba y reconstrucción hipotética de los mismos. Arriba: Fragmento de posible capitel eólico. Abajo: Fragmento de placa decorada con cáliz y palmeta (Portillo 2016b: tomo II, 310, lám. 168; 535, lám. 6) (dibujo J. Borrego y Ana Portillo).

pieza, $6,7 \mathrm{~cm}$ es significativo, aunque podría contar aún con una dimensión mayor, ya que la cara posterior ha sufrido un desprendimiento y se muestra incompleta. El tipo de palmeta representada aquí vuelve a repetir el modelo de extremidades cóncavas, que ya veíamos en uno de los fragmentos localizados en la calle Cruz Conde, en el que el último tramo de los brazos y las puntas gira hacia el tallo o brazo central. Difiere en este sentido del otro modelo documentado, en el que la continuidad de la línea que marcan los brazos de la palmeta esboza una tipología centrífuga de extremos convexos.

Finalmente, la tercera pieza presenta una superficie lisa y pulida en la cara posterior y un fino trabajo de talla en la anterior. En esta última aparece una voluta corpórea, con gran desarrollo, en cuyo interior han sido labrados pares de hojitas lisas unidas por los extremos, que crean un contraste de luces y sombras, proporcionando así dinamismo a la pieza (fig. 13). Su morfología y espesor $(7,7 \mathrm{~cm})$, nos llevan a proponer su ubicación en la cabecera del respaldo del thronos, aunque por el estado fragmentario de la pieza, tampoco tenemos seguridad sobre esto.

Nos centraremos ahora en otro de los espacios religiosos de Colonia Patricia (Córdoba, Córdoba), el complejo de culto de la calle Claudio Marcelo, presidido por un templo hexástilo dedicado al culto imperial (Garriguet 2014; Gutiérrez 2016, con numerosa bibliografía precedente). En este espacio fue localizada una pieza interpretada inicialmente como un fragmento de capitel compuesto (Gutiérrez 2016: 380, lám. LXXII), pero que nosotros relacionamos preferentemente, por cuestiones formales, con un posible fragmento de trono marmóreo (fig. 14). 

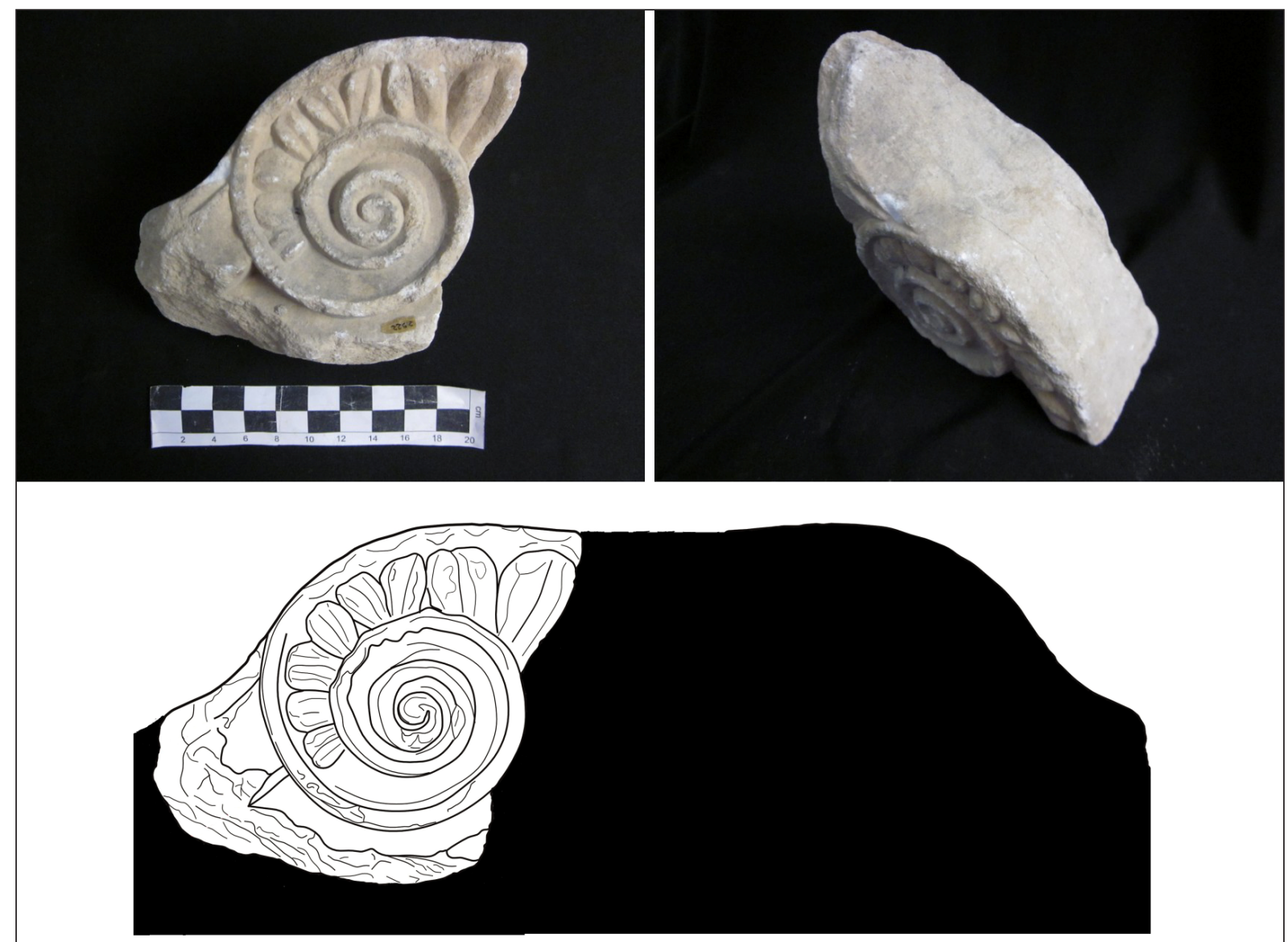

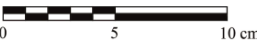

Figura 13. Fragmento de posible respaldo de trono marmóreo procedente de la calle Morería, Córdoba y reconstrucción hipotética del mismo. (Portillo 2016b: tomo II, 537, lám. 7) (dibujo J. Borrego y Ana Portillo).

A nivel morfológico, se trata de un fragmento del remate superior de la pata del thronos y parte de uno de los travesaños horizontales o reposabrazos. La pieza cuenta con una profundidad máxima conservada de $17 \mathrm{~cm}$, de los cuales 5 corresponden al grosor de la placa relivaria y los 12 restantes al travesaño. La única decoración existente se encuentra en la cara anterior de la placa, que adopta una forma circular de voluta, en cuyo canal interior hallamos una serie de roleos de acanto de talla muy naturalista. En el centro de esta composición se conserva parte de lo que parece ser una flor tetrapétala, aunque únicamente podemos observar dos pétalos incompletos. Por los motivos ornamentales empleados y el tipo de labra, otorgaríamos a esta pieza una cronología julio-claudia, asociándola al interior de la cella de este templo como parte del mobiliario litúrgico.

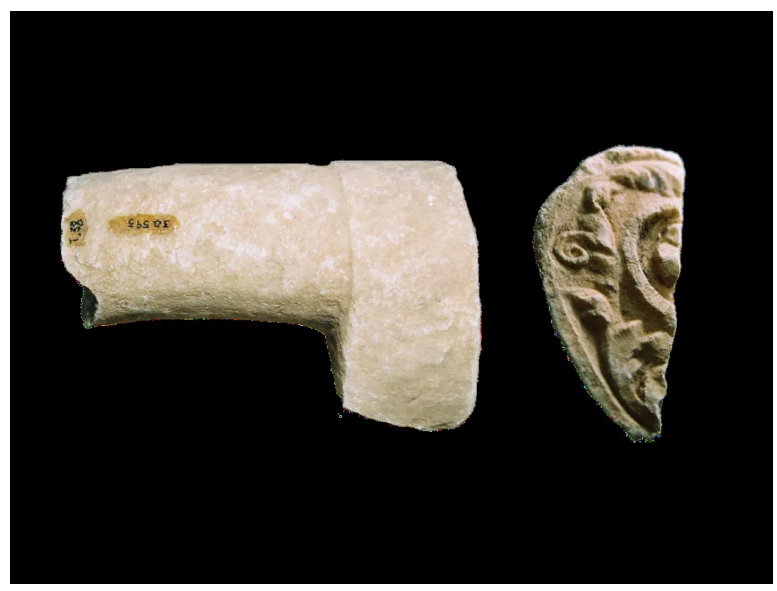

Figura 14. Posible fragmento de trono marmóreo procedente del templo de la calle Claudio Marcelo, Córdoba (Gutiérrez 2016: 479, lám. LXXII, OT011 NR 257). 

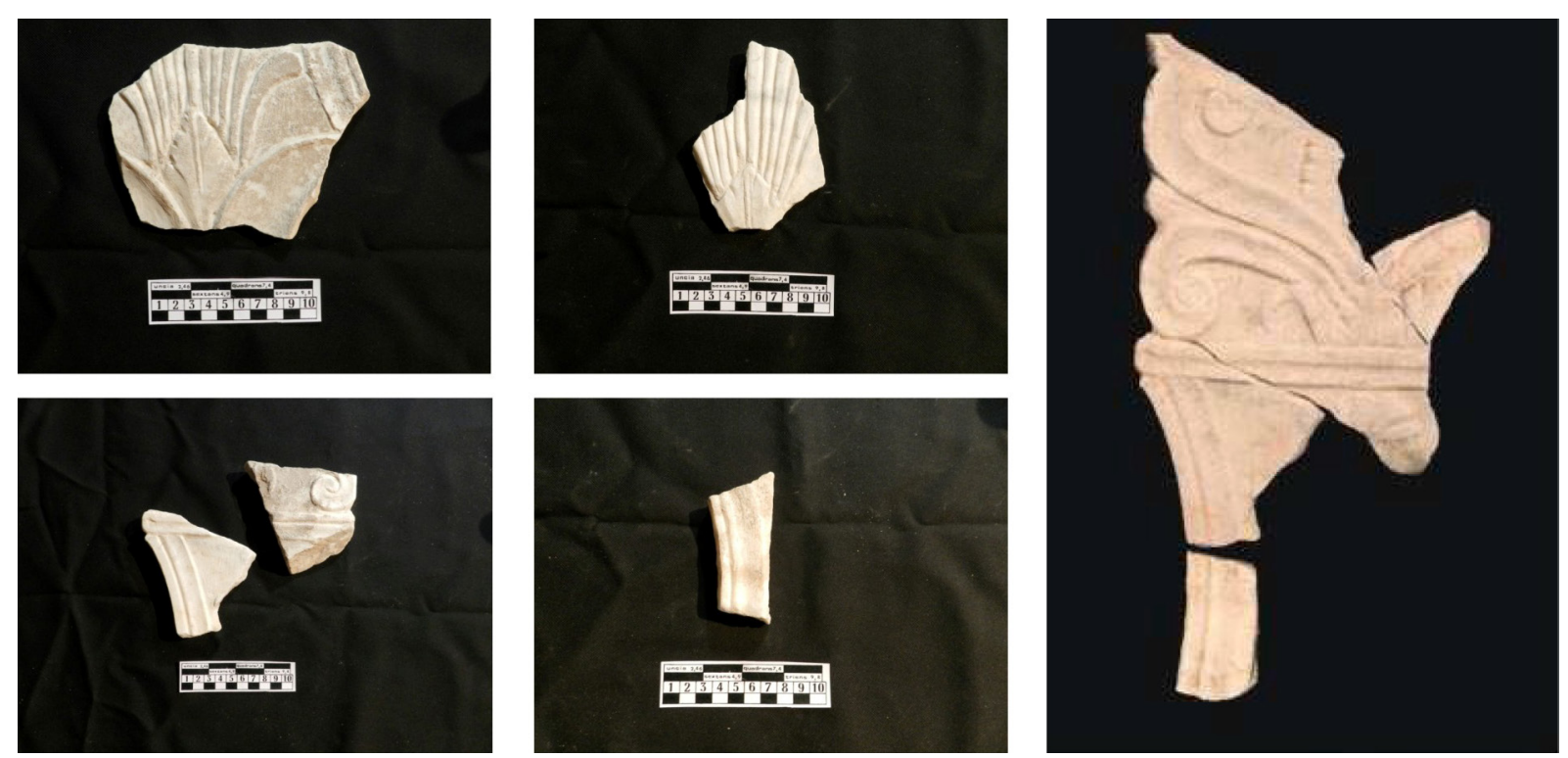

Figura 15. Fragmentos de tronos procedentes del foro de Ituci Virtus Iulia, Torreparedones (Baena, Córdoba) (derecha: BorregoFelipe 2014: 108, fig. 10).

\subsubsection{Ituci Virtus Iulia}

Recientemente fueron localizados una serie de fragmentos de tronos en el entorno del foro de Ituci Virtus Iulia, en el yacimiento de Torreparedones (Baena, Córdoba) (Borrego y Felipe 2014). Esta serie se compone de once pequeñas plaquitas de mármol blanco de grosores que oscilan entre los 1,5 y $2,5 \mathrm{~cm}$, que permiten restablecer al menos dos modelos de patas de trono (fig. 15). En ellas podemos constatar la presencia de los dos tipos de palmetas antes analizados, de extremidades cóncavas y convexas, además de hallar pequeños fragmentos de algunos de los dobles listeles lisos que adornarían los bordes o límites perimetrales del thronos.

Contamos con dos fragmentos de palmeta convexa, cuyos extremos de los brazos caen al exterior, que surgen de una hoja central con forma de punta de lanza, bajo la cual atisbamos la presencia de dos grandes volutas. El otro esquema se compone de una palmeta de extremos cóncavos, suponemos que de cuatro brazos, que nace de un cáliz abierto. El número par de los tallos de este modelo es algo inusual en este tipo de representaciones, pero en este caso, quedaría justificado por la presencia de un motivo figurativo que pensamos que podría ocupar el eje de la composición de esta pieza. En el lado izquierdo de esta placa se conserva parte de una ínfula que cae en posición vertical. Según indican J. Borrego y A. Felipe (2014: 109), este detalle podría ser la clave para pensar en la existencia de un bucráneo o una testa de toro engalanado, que serviría para evocar ese carácter sacro del elemento mueble y su contexto, presidiendo así toda la composición. En todos estos ejemplos y a pesar de que las formas resultan ser de carácter orgánico y naturalista, apreciamos una talla muy plana, con poca profundidad entre el fondo y el elemento decorativo. Estas piezas estarían vinculadas a los edificios públicos del foro de la ciudad (templos, basílica, etc.) (Ventura 2014), con los que se establecen unas relaciones proporcionales coherentes con los soportes hallados en este particular. Además, la presencia de tronos marmóreos en Ituci queda justificada igualmente por el hallazgo en el foro de esta ciudad de distintas esculturas sedentes tanto femeninas (se cuenta con un solo ejemplar interpretado como representación de diosa o emperatriz asimilada a alguna divinidad o virtud imperial) como masculinas (dos figuras interpretadas como las representaciones de los emperadores Augusto y Claudio como divi), tipologías escultóricas que vendrían a ocupar este tipo de asientos (Márquez 2014: 93-97).

\subsubsection{Mirobriga?}

Para concluir los ejemplos béticos, nos centraremos en una pieza conservada en el Museo Nacional de Arqueología de Portugal (Lisboa), procedente de Castelo 
Velho de São Braz (fig. 16), la cual resulta del mayor interés, pues a pesar de que se encuentra catalogada como un fragmento de placa relivaria, pensamos que podría haber formado parte de uno de estos thronoi. Se trata de una pequeña placa (altura máx: $14,5 \mathrm{~cm}$, anchura máx: $12 \mathrm{~cm}$, profundidad: $2,5 \mathrm{~cm}$ ) elaborada en mármol blanco, con los extremos cóncavos decorados por un listel liso que sirve de marco a la composición. Presenta una decoración interior en la que aparece una palmeta de once brazos cóncavos que emerge de una hojita apuntada. El primer factor que debemos observar es lo ajustado que resulta el motivo ornamental en relación con el espacio disponible, ocupando toda la superficie y creando una cierta sensación de estrechez. Por otro lado, presenta una talla definida y muy orgánica, acentuada con los toques de trépano realizados entre los lóbulos de la hoja inferior, que aportan naturalidad y contrastes de luces y sombra a la pieza.

Por el lugar de procedencia (Vasconcelos 1913: 315 ), podríamos proponer de forma hipotética su ubicación original en el interior de la cella del templo de culto imperial de la ciudad de Mirobriga (Capilla, Badajoz) (Santos 1998a; 1998b: 91-92.), un edificio sacro muy parecido en proporciones y fisionomía al templo principal del foro de Ituci Virtus Iulia (Torreparedones, Baena Córdoba), contexto al que muy probablemente pertenecieran los fragmentos de trono anteriormente analizados recuperados en dicho foro y con los que coincide, en las dimensiones del grosor, la placa portuguesa.

\subsection{Tarraconensis}

\subsubsection{Villa de "Los Quintanares" (Rioseco de Soria)}

De esta provincia traemos a colación dos ejemplos bien diferenciados. De un lado, una serie de piezas procedentes de la villa de "Los Quintanares" (Rioseco de Soria), cuya interpretación ha sido debatida por distintos autores. Se trata de un conjunto de cuatro placas marmóreas decoradas con motivos vegetales y elementos rituales (fig. 17), definidas por su excavador como revestimientos de pilastras y jambas para la decoración de algunas estancias termales de este enclave (Ortego 1979: 359-373). Formalmente nos encontramos ante placas rectangulares con los lados curvos, una morfología que no encaja bien con la tipología habitual de este tipo de elementos arquitectónicos, ya que las pilastras suelen responder a esquemas de extremos rectos. Este es el argumento principal que esgrimen otros autores para definir a estas piezas como soportes de muebles

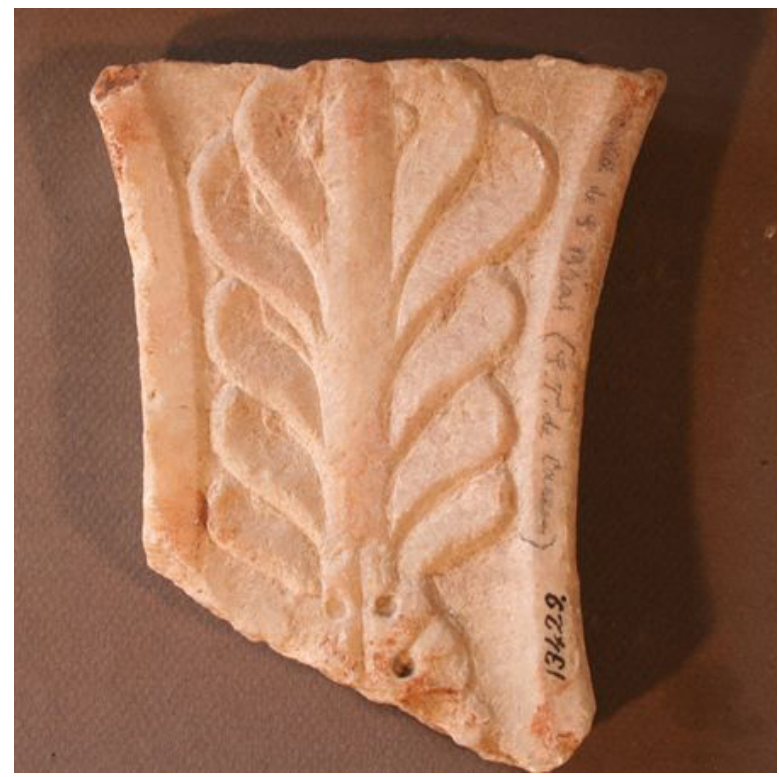

Figura 16. Fragmento de placa decorada, posible fragmento de trono marmóreo, procedente Castelo Velho de São Braz (Portugal). (Museu Nacional de Arqueologia, Lisboa, Portugal. $\mathrm{N}^{\mathrm{o}}$ de inventario: 13429) (foto http://www. matriznet.dgpc.pt/MatrizNet/Objectos/ObjectosConsultar. aspx?IdReg=140726).

de la villa y más concretamente, como parte integrante de algún tipo de asiento o lecho (Gutiérrez 1995: 74). La forma curvada de los lados de las placas estaría indicando esta funcionalidad. En cuanto a la decoración, creemos que este es el elemento clave para determinar el uso de estos soportes. La pieza de mayor tamaño presenta una decoración interior presidida, en su zona superior, por una crátera que sirve de eje a la composición. Bajo esta se desarrolla un lenguaje vegetal en el que los roleos, rosetas y cálices de distintos tamaños parecen ser los principales protagonistas.

El otro fragmento pertenecería a un soporte distinto, pues su ornamentación difiere de la anterior. En este caso encontramos una serie de motivos decorativos de carácter cultual en el extremo superior de la pata, como un bucráneo engalanado con ínfulas, una pátera y otro elemento de difícil interpretación, probablemente un cuchillo sacrificial, debido al estado fragmentario de la pieza. Descendiendo, hallamos un listel liso que enmarca una composición orgánica en la que únicamente podemos distinguir la presencia de dos roleos enlazados cuyos extremos se rematan con una flor tetrapétala. La presencia de este lenguaje sacro estaría indicando su vinculación a un espacio religioso de esta villa (Ortego 1977), en el que serían usados, al menos los fragmentos 

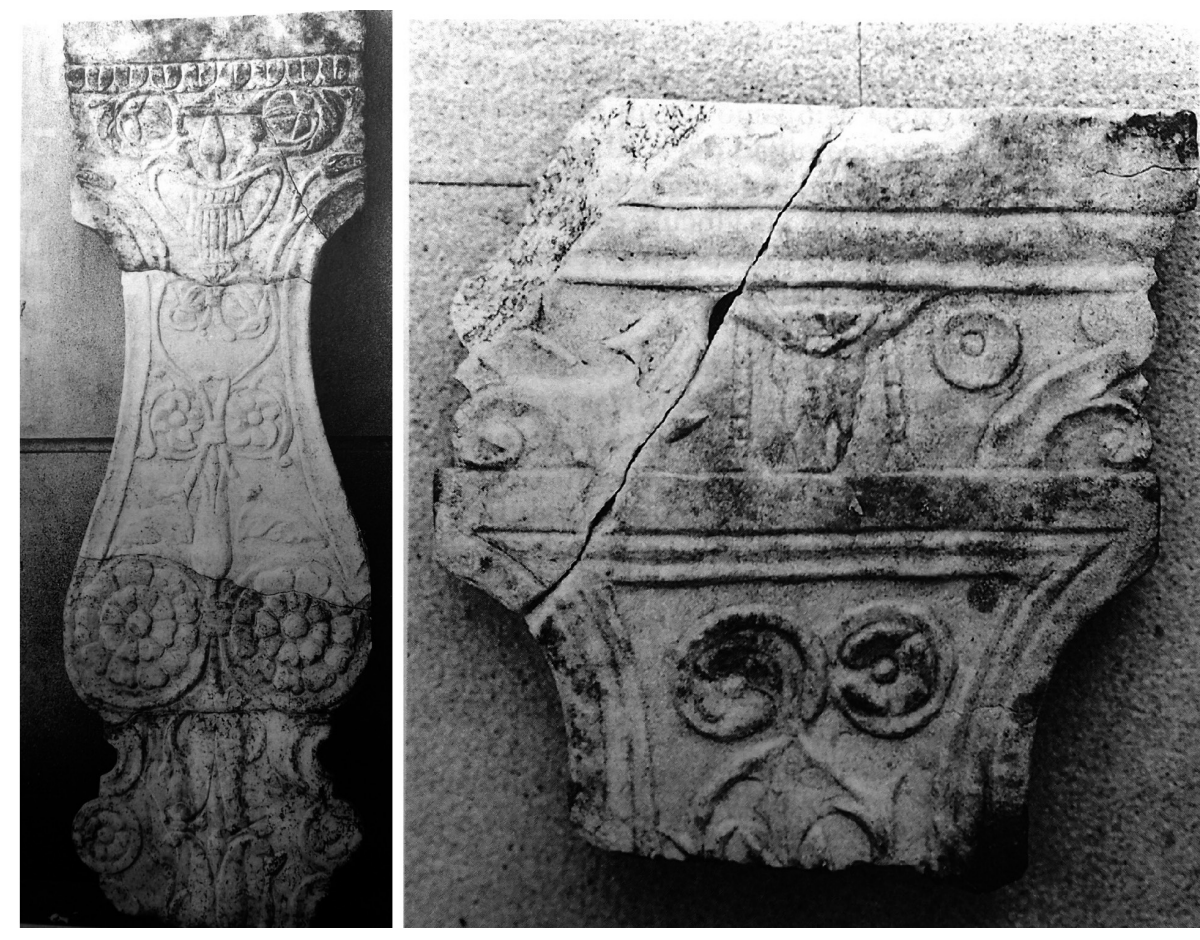

Figura 17. Fragmentos de placas relivarias, posibles tronos marmóreos procedentes de la Villa de "los Quintanares", (Rioseco, Soria) (Gutiérrez 1995: 74, fig. 1 y 75 , fig. 2).

correspondientes a esta pieza, como parte del soporte de tronos o lechos empleados en banquetes rituales (Gutiérrez 1995: 75).

\subsubsection{Colonia Iulia Vrbs Triumphalis Tarraco}

Por otro lado, el Museo Nacional de Arqueología de Tarragona (MNAT) conserva entre sus fondos una pieza de formato mediano interpretada como una representación de Ceres o Fortuna sentada sobre trono datada en el siglo II d.C. (García y Bellido 1949: Lám. 127, $\mathrm{n}^{\circ}$ 168) (fig. 18). En este caso se trata de un soporte liso y muy sencillo, con alto respaldo rematado en frontón triangular. En la zona del asiento se ha colocado un cojín (pulvinus) sobre el que apoya directamente la figura femenina y bajo este, observamos unas patas sin decoración, en las que únicamente se aprecian los elementos de unión de las mismas, como la moldura central o el travesaño lateral que conecta las patas delanteras con las traseras. Este ejemplar no aporta mucha información, pero sí resulta interesante desde el punto de vista morfológico, para constatar la presencia de determinadas formas en la composición de estos thronoi, por ejemplo algunos elementos arquitectónicos tales como el frontón triangular, que pasan a la escultura funcionando como remates en algunas versiones de estos soportes, como los de alto respaldo, hecho que ya vimos repetido en el caso del thronos del emperador Calígula en Nemi.

\subsubsection{Mazarrón (Murcia)}

El Museo Arqueológico Provincial de Murcia conserva entre sus fondos un excepcional grupo escultórico de época flavia (Noguera 1992: 93-94), procedente de la localidad de Mazarrón (Murcia), compuesto por dos figuras togadas de genii y un personaje femenino sedente que representa a Terra Mater, dedicados por el dispensator Albanus, tal y como lo indican los epígrafes votivos de cada uno de sus pedestales. Los personajes masculinos se encuentran labrados en piedra arenisca, mientras que la figura entronizada está elaborada en cuarcita. Como dato interesante conviene señalar que todas estas piezas conservan restos de estuco en la superficie, además de varias capas cromáticas de tonalidad rojiza distribuidas en distintas zonas de las figuras y en las letras de los epígrafes (Noguera 2001-2002: 396).

De entre ellas, vamos a centrarnos en la figura femenina (fig. 19), pues es la que resulta de interés para este estudio en particular. La divinidad se dispone sobre un asiento sin respaldo cuyas patas han sido hábilmente elaboradas a base de motivos orgánicos como 


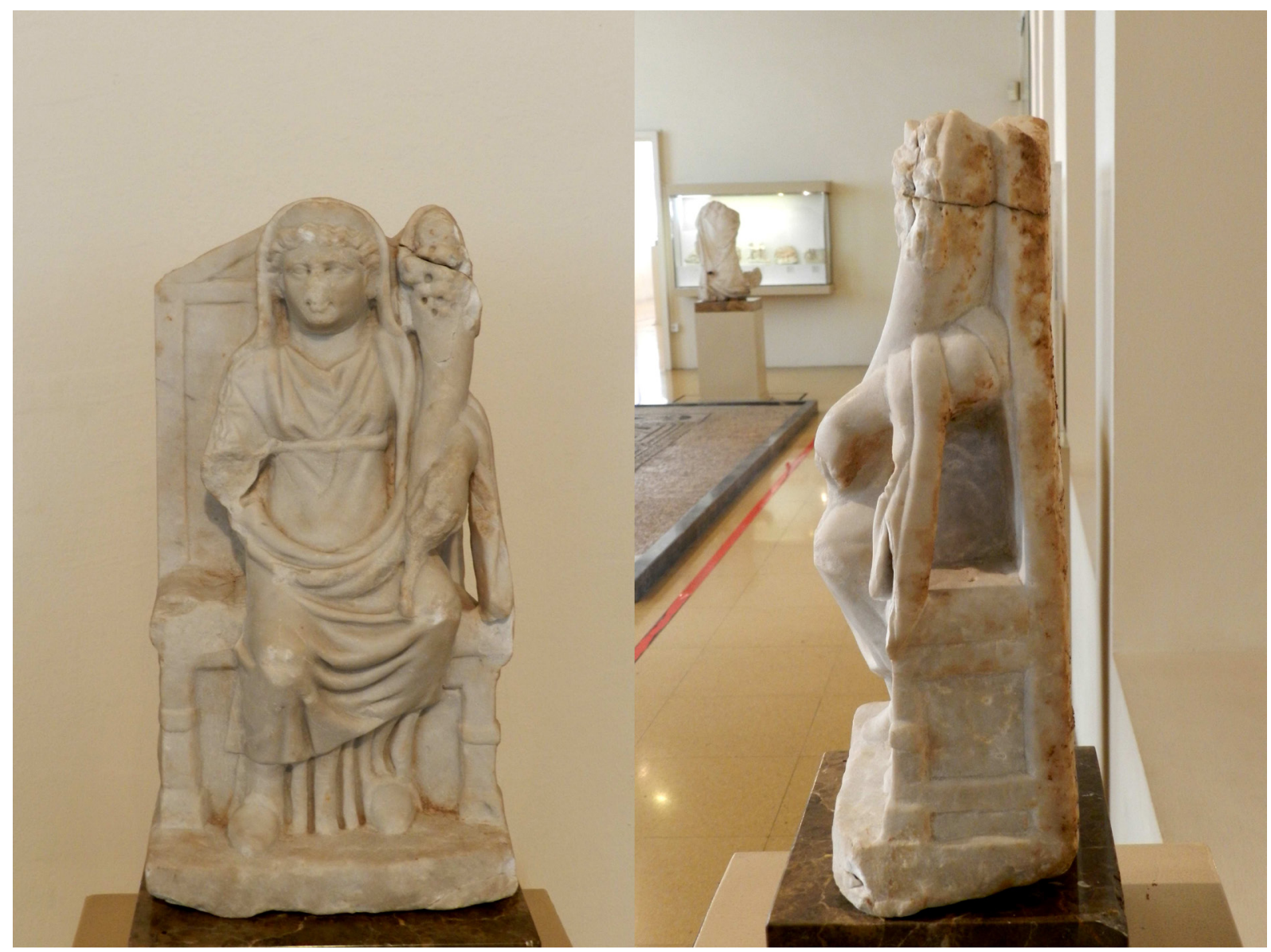

Figura 18.Ceres o Fortuna entronizada. Procedente de una villa de la ribera del río Francolí (Museo Nacional de Arqueología de Tarragona. $\mathrm{N}^{\circ}$ de inventario: 12354).

corolas de flores invertidas y molduras que imitan, de manera excelente, el trabajo de la madera (fig. 20). La condición de benefactora de la naturaleza de la deidad representada, así como su vinculación con la regeneración y la fertilidad, se establecen aquí como factores fundamentales a la hora de seleccionar los motivos ornamentales de carácter organicista que componen este mueble, pues como venimos señalando en este trabajo, el lenguaje decorativo de los tronos suele estar relacionado con el personaje representado.

Las formas se presentan bien definidas, con un interesante juego de claroscuros que se origina por la combinación de molduras cóncavas y convexas, aportando un cierto dinamismo a la composición. El remate superior de las patas se resuelve con una base cuadrangular sobre la que apoya un pequeño cilindro liso. En la zona del asiento se ha colocado un mullido cojín cubierto con un amplio manto con los bordes decorados por flecos, que cae sutilmente por los extremos laterales del soporte, creando una cascada de pliegues de factura naturalista. En este caso, observamos la presencia de un escabel liso, carente de decoración alguna, cuya única misión aquí es dar reposo a los pies de la deidad y evitar, precisamente por su condición divina, el contacto de éstos con la tierra, elevándola y otorgándole una cierta dignidad a la imagen.

\subsection{Lusitania}

\subsubsection{Augusta Emerita}

De esta provincia traemos a colación un único ejemplar procedente de la capital de la misma, hallado en 1926 al final de la calle Constantino junto con otras piezas escultóricas, algunas de ellas de divinidades infernales, según nos informa A. García y Bellido (1949: 156). Se trata de una figura femenina sedente e 


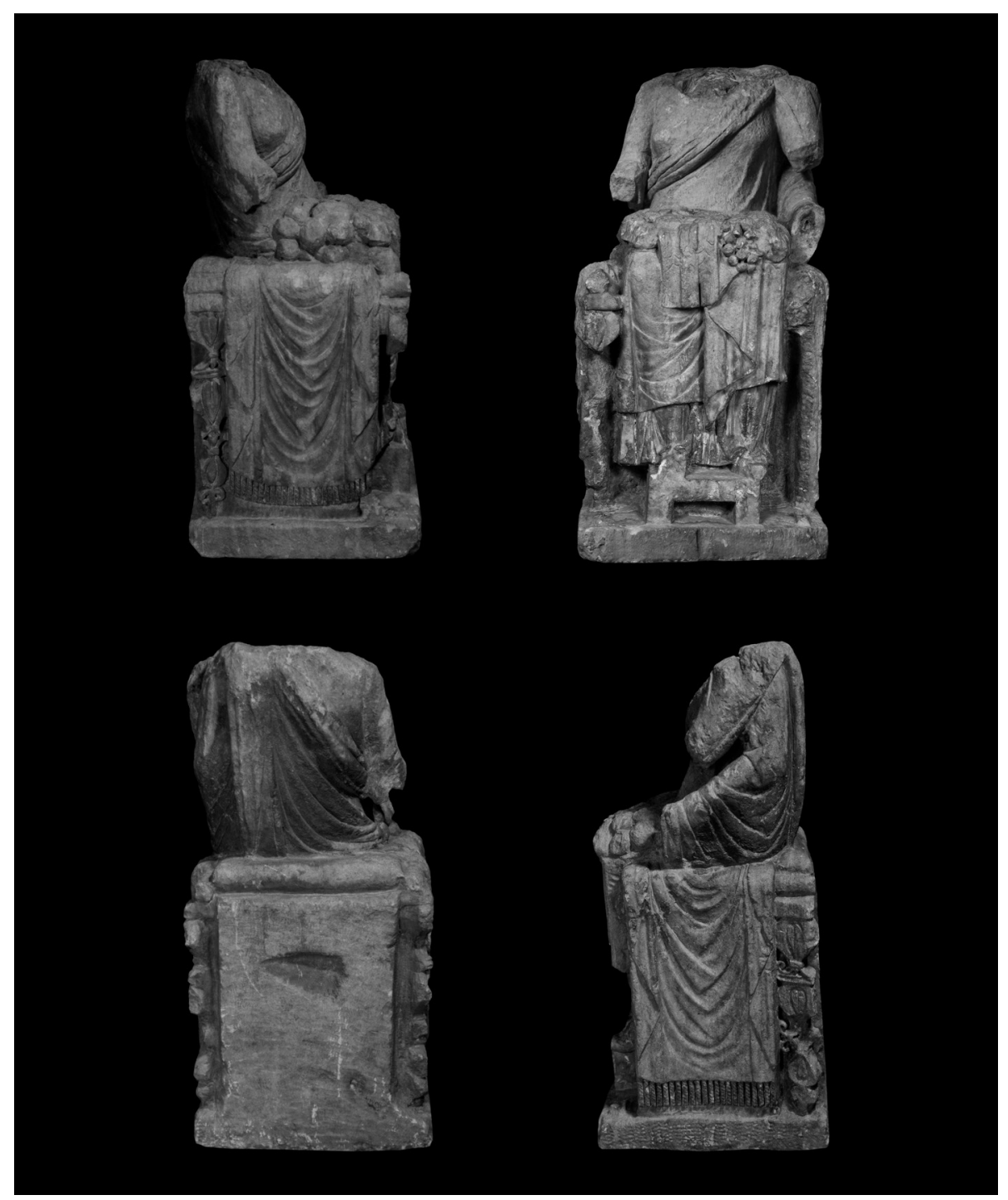

Figura 19. Figura de Terra Mater de Mazarrón, vistas frontal, dorsal y laterales (Noguera 2001-2002: 401, Lám. 3).

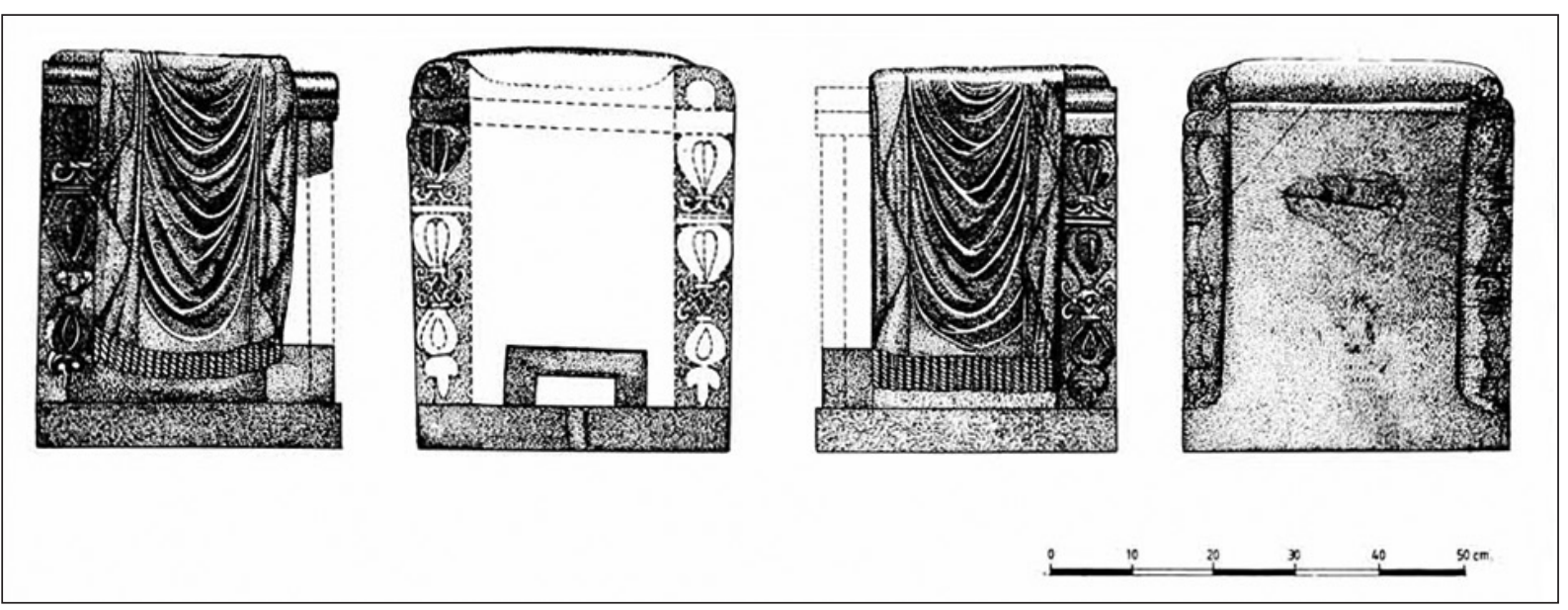

Figura 20. Reconstrucción de la sella de Terra Mater de Mazarrón (Noguera 1992: 87, fig. 4). 
incompleta, faltándole los hombros, el cuello, la cabeza y ambas extremidades superiores desde la zona del antebrazo hacia la mano (fig. 21). La pieza aparece sobre un trono de aspecto cúbico, del que únicamente distinguimos el reposabrazos (por lo que intuimos que se trataría de un asiento con respaldo) y la cara anterior de las patas delanteras. En ellas se aprecia la única decoración existente, en la que observamos dos serpientes (una a cada lado) que parecen ascender por la superficie hasta tocar una flor tetrapétala con botón central, con la que se remata la composición en el extremo superior de cada pata. Otro elemento interesante es el escabel que, si bien aparece elaborado en bajorrelieve, prácticamente esbozado y liso, sin ningún tipo de ornamento, con su presencia vuelve a dar testimonio de la estrecha relación existente entre el thronos y este pequeño soporte, que suele acompañar, en la mayor parte de los casos, a esta tipología de asientos.

El mismo autor la interpreta como una posible Proserpina, dada la presencia de las serpientes, pero la falta del busto así como de distintos atributos, le hace adoptar una actitud cauta, sin desechar otras identificaciones. Las serpientes estaban asociadas al inframundo y eran entendidas como símbolo de fertilidad y regeneración, distintivo de la Tierra personificada, por ello nos parece una atribución razonable. La talla y forma de los pliegues del ropaje le hacen datarla a mediados del siglo II d.C., proponiendo de forma hipotética como procedencia original, el mitreo del Cerro San Albín.

\section{CONCLUSIONES}

Hemos tenido oportunidad de observar cómo el thronos constituye un elemento escultórico de gran importancia, capaz de transmitirnos una información sustancial tanto del personaje que lo ocupa, como del contexto al que pertenece. En cualquiera de sus múltiples variantes, podemos determinar que se trata de un soporte asociado a un grupo específico de la sociedad y muy especialmente, a divinidades. A través de ellos es posible estimar la entidad de la figura representada, pues habitualmente el grado de elaboración de los mismos, los materiales empleados y su decoración serán signos indicativos de la posición o relevancia del personaje, su entorno y de los comitentes que solicitan la obra. Más interesantes resultan ser los casos que presentan figuración, ya que en ellos el thronos adquiere un carácter narrativo, valiéndose frecuentemente de imágenes muy concretas como alegorías o figuras simbólicas, que comuniquen un hecho específico

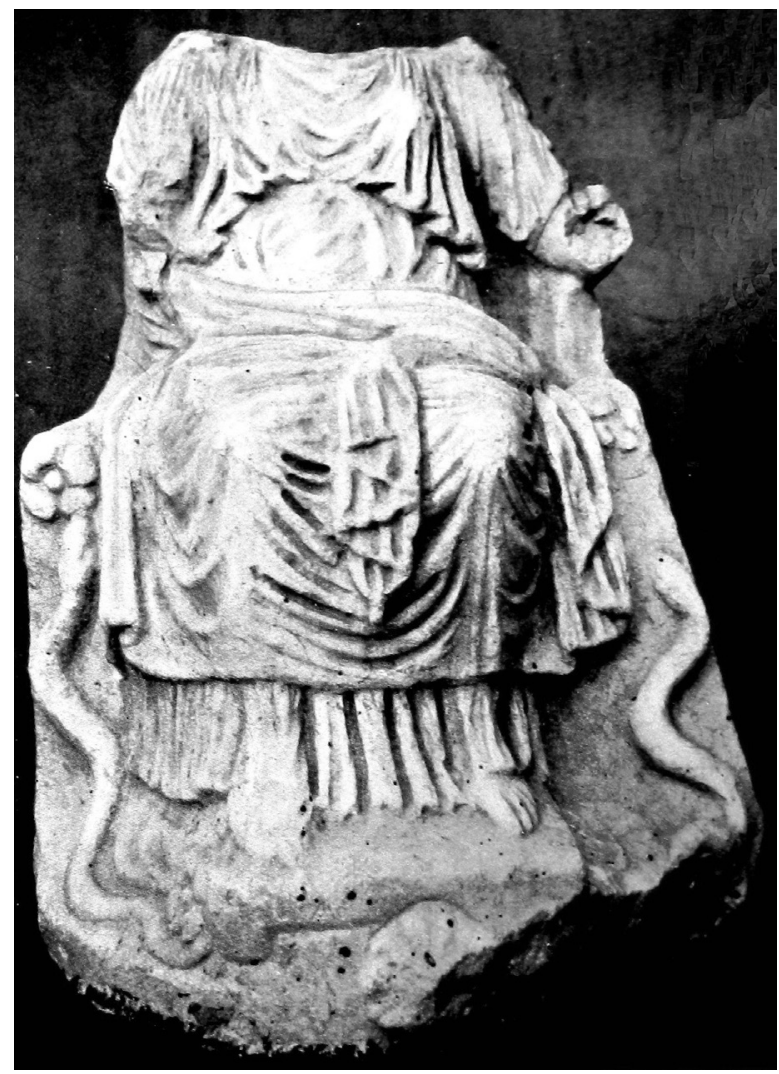

Figura 21. Figura femenina entronizada. (Museo Nacional de Arte Romano, Mérida) (García y Bellido 1949: Lám. 126, n 167).

o transmitan alguna información del representado, convirtiéndose así en un instrumento muy útil para averiguar la identidad y magnitud del sujeto.

En este sentido es interesante observar cómo el thronos se convierte en el lienzo de la efigie que lo ocupa. De estar presente, el personaje se muestra habitualmente en actitud reposada y contemplativa, alejado de toda acción, envuelto en la serenidad imperturbable de los dioses. Es por tanto el asiento el que va a convertirse en el documento, en la fuente de información capaz de surtir al observador de los detalles necesarios que otorguen sentido y carácter a la figura. Hasta en los casos en que estos soportes parecen estar elaborados de forma estandarizada, existen pequeñas particularidades en la ornamentación de los mismos, que nos señalan las diferencias existentes entre distintos personajes. Un ejemplo de ello lo encontramos en los tronos de $D i$ vus Augustus y Claudio del Augusteum de Herculano (fig. 10). En estos casos se representa a los emperadores empleando el mismo modelo escultórico divinizado; sin embargo, las patas delanteras del thronos 
del Divus Augustus presentan una ligera variación en la pieza central que une los extremos superior e inferior de la misma. Se observa aquí un elemento con un perfil más refinado y elegante, con una moldura de lados cóncavos acabados en volutas que no vemos en el otro ejemplar. Esta diferencia permite suponer la intención premeditada de distinguir al personaje entronizado a través de la introducción de pequeños rasgos ornamentales en el asiento, que lo singularicen y le hagan destacar. En este particular, el hecho cobra sentido al tratarse del único divus de los dos emperadores representados, siendo además la figura a quien se le dedica el espacio que ocupó en origen, el Augusteum.

Cuando el thronos aparece vacío, habría que entenderlo como símbolo de poder y representación, o bien de un soberano o de alguna divinidad, ya que se entiende que el personaje al que se le dedica, desciende o está simbólicamente presente en este objeto durante el desarrollo de las actividades que se ejecuten en el contexto donde se inserte. La presencia de estas piezas en ciertos ambientes puede resultar también de gran ayuda a la hora de establecer una función concreta para determinados espacios, además de convertirse en una fuente muy práctica, para fijar los modelos estatuarios de un lugar específico. Por ello, es fundamental ser precisos en su identificación, evitando así las más que frecuentes confusiones de éstos como materiales de decoración arquitectónica. Por otro lado, la existencia de thronoi igualmente nos aporta información sobre algunas de las actividades de carácter cultual desarrolladas en ámbitos sacros, como los sellisternia. Este hecho resulta ser de gran interés, pues nos ayuda a acercarnos a las prácticas rituales y religiosas del pueblo romano, además de contribuir al conocimiento del mobiliario litúrgico empleado en el interior de las cellae de los templos, en el intento de recrear la distribución interna de estos recintos, un asunto del que, a día de hoy, contamos con muy pocos datos.

Por tanto y a modo de apunte final, nos parece fundamental llamar la atención sobre la importancia de este tipo de piezas, debido a la gran cantidad de información que pueden aportar, así como por su rareza, pues desafortunadamente no son muy numerosos los ejemplos con los que contamos, sobre todo si se trata de piezas completas. En el caso concreto de Hispania, marco que hemos seleccionado para este estudio, creemos que existe un abundantísimo campo de trabajo aún sin abordar en este asunto, que sobrepasaría con creces los objetivos trazados para el análisis que presentamos en estas páginas. Por ello, nos hemos contentado con aportar nuevos fragmentos (fig. 11-D, 12, 13 y 14) que incrementen el conocimiento de esta tipología e igualmente, con llevar a cabo una revisión o reinterpretación de alguna pieza, como en el caso del fragmento portugués (fig. 16), que asociamos a estos soportes.

Falta aún por realizar una búsqueda sistemática de estos elementos a través de las bases de datos de los Museos o en los fondos de los mismos, en catálogos de materiales procedentes de yacimientos, etc. Las capitales de las provincias hispanas ofrecerán más posibilidades de contener entre sus restos materiales esta interesante tipología mobiliaria, pero igualmente habrían de ser rastreados en las capitales de conuentus iuridicus o bien en las ciudades más destacadas de cada territorio. Con ello animamos a la comunidad científica a estar alerta ante la presencia de estos soportes, ya que han demostrado ser verdaderos y magníficos instrumentos para el conocimiento de la ideología y prácticas de la civilización romana.

\section{Agradecimientos}

Quisiéramos dar las gracias al Prof. Dr. A. Ventura, así como a la Dra. A. Felipe y a J. A. Morena, por las facilidades proporcionadas para poder llevar a cabo el estudio de las piezas conservadas en el Museo Histórico de Baena (Córdoba). Igualmente queremos hacer extensible nuestro agradecimiento a la Dra. M. I. Gutiérrez por poner a nuestra disposición la documentación gráfica del material arqueológico correspondiente al templo de la calle Claudio Marcelo (Córdoba) y al Prof. Dr. J. M. Noguera Celdrán por facilitarnos la imagen de la representación de Terra Mater del grupo escultórico de Mazarrón (Murcia).

\section{BIBLIOGRAFÍA}

Baena, L. (2011): "La tradición clásica en las matronas sedentes de Hispania", en T. Nogales e I. Rodà (eds.), Roma y las provincias: modelo y difusión: Actas del XI Congreso Internacional de Arte Romano Provincial: vol. II, 963-969. Mérida (2009), Roma, L'Erma di Bretschneider.

Balil, A. (1975): "Sobre el mobiliario romano". Revista de Guimarães LXXXV: 69-90.

Bell, R. (2007): Power and Piety: Augustan imagery and the cult of the Magna Mater. Tesis Doctoral, Universidad de Canterbury. Inédita.

Bell, R. (2009): "Revisiting the pediment of the Palatine metroön: a Vergilian interpretation". Papers of the British School at Rome 77: 65-99. 
Bendala, M. (2010): "La Dama de Baza: el modelo de la dama sedente, su contexto y su problemática", en T. Chapa y M. I. Izquierdo (eds.), La Dama de Baza: Un viaje femenino al más allá, Actas del Encuentro Internacional, Museo Arqueológico Nacional: 171-184. Madrid (2007), Madrid, Ministerio de Cultura, Subdirección General de Publicaciones, Información y Documentación.

Borrego, J. y Felipe, A. (2014): "La decoración arquitectónica”, en C. Márquez, J. A. Morena, R. Córdoba y A. Ventura (eds.), Torreparedones, Baena-Córdoba, Investigaciones arqueológicas (2006-2012): 99-109. Córdoba, Universidad de Córdoba, Excmo. Ayuntamiento de Baena.

Caneva, G. (2010): Il codice botanico di Augusto. Roma-Ara Pacis. Parlare al popolo attraverso le immagini della natura. Roma, Gangemi.

Cuadrado, E. (1995): "La dama sedente de El Cigarralejo (Mula, Murcia)", en Actas del XXII Congreso Nacional de Arqueología, vol. 2: 247-250. Vigo (1993), Xunta de Galicia, Consellería de Cultura, Comunicación Social e Turismo.

De Carolis, E. (2007): Il mobile a Pompei ed Ercolano. Letti, tavoli, sedie e armadi. Contributo alla tipologia dei mobili della prima età imperiale. Roma, L'Erma di Bretschneider.

Foletti, I. (2011-2012): "Sicut in Caelo et in Terra. Osservazioni sulla cathedra vacua della basilica sistina di Santa María Maggiore a Roma". Iconographica X-XI: 33-46.

García y Bellido, A. (1949): Esculturas romanas de España y Portugal. Madrid, CSIC.

Garriguet, J. A. (2012): "Del trono al cielo: la divinización del gobernante en el mundo romano", en $A n$ dalucía en la Historia: 42-45. Sevilla, Centro de Estudios Andaluces.

Garriguet, J. A. (2014): “Sobre el modelo, cronología y posible dedicación del templo romano de la $\mathrm{C} /$ Claudio Marcelo, Córdoba. Apuntes arqueológicos e históricos", en F. Lozano, P. Giménez y C. Alarcón (eds.), Reyes y dioses: la realeza divina en las sociedades antiguas, Arys 12: 238-267. Madrid, Universidad Carlos III.

Ghini, G. (2014): "La statua del Princeps, il suo contesto e le ville del bacino nemorense", en G. Ghini, A. Palladino y M. Rossi (a cura di), Sulle tracce di Caligola. Storie di grandi recuperi della Guardia di Finanza al lago di Nemi, Catalogo della mostra: 4953. Roma (2014), Roma, Gangemi.

Guillén, J. (2004): Urbs Roma: Vida y costumbres de los romanos, vol. III. Salamanca, Sígueme.
Gutiérrez, M. A. (1995): "Placas de mármol procedentes de la villa de Los Quintanares", en Homenaje al profesor J. J. Martín González: 73-76. Valladolid, Universidad de Valladolid.

Gutiérrez, M. I. (2016): Análisis de un centro de culto imperial de la Córdoba romana: El conjunto arquitectónico de la c/ Claudio Marcelo. Tesis Doctoral, Universidad de Córdoba. Inédita.

Izquierdo, I. y Le Meaux, H. (coord.) (2003): Seres hibridos. Apropiación de motivos míticos mediterráneos. Actas del seminario-exposición. Madrid (2002), Madrid, Ministerio de Educación, Cultura y Deporte, Casa Velázquez.

Kottaridou, A. (2006): “Couleur et sens: l'emploi de la couleur dans la tombe de la reine Eurydice", en Rois cités, nécropoles: Institutions, rites et monuments en Macédoine, Actes du Colloques de Nanterre (2002) et d' Athènes (2004). Meletimata 45: 155-168. Atenas, De Boccard.

La Rocca, E. (1994): “Ara Pietatis Augustae”, en Enciclopedia dell'arte antica. Secondo supplemento 1971-1994, t. I: 320-321. Roma, Istituto Giovanni Treccani.

La Rocca, E. (2007): "I troni dei nuovi dei”, en T. Nogales y J. González (eds.), Culto imperial: política y poder: 77-104. Mérida (2006), Roma, L'Erma di Bretschneider.

Lapatin, K. (2014): "The throne of Nemi and Olympian Zeus", en G. Ghini, A. Palladino y M. Rossi (a cura di), Sulle tracce di Caligola. Storie di grandi recuperi della Guardia di Finanza al lago di Nemi, Catalogo della mostra: 55-57. Roma (2014), Roma, Gangemi.

Levi, A. (1931): Sculture greche e romane del Palazzo Ducale di Mantova. Roma, L'Erma di Bretschneider.

Madigan, B. (2013): The ceremonial Sculptures of the Roman Gods. Monumenta Graeca et Romana 20. Leiden-Boston, Brill.

Marcks, C. (2013): "Más que la suma de sus componentes: consideraciones sobre el $<<$ trono $>>$ de la colección de antigüedades de Gustavo III rey de Suecia”, en M. Clavería (ed.), Antiguo o moderno. Encuadre de la escultura de estilo clásico en su periodo correspondiente: 145-161. Barcelona, Universidad Autónoma de Barcelona.

Márquez, C. (1997): “Artes decorativas en la Córdoba romana". Anales de Arqueología Cordobesa 8: 69-94.

Márquez, C. (1998a): La decoración arquitectónica de Colonia Patricia. Una aproximación a la arquitectura y al urbanismo de la Córdoba romana. 
Córdoba, Universidad de Córdoba, Obra Social y Cultural Cajasur.

Márquez, C. (1998b): “Acerca de la función e inserción urbanística de las plazas en Colonia Patricia". Empúries 51: 63-76.

Márquez, C. (2004): "La decoración arquitectónica en Colonia Patricia en el periodo julio-claudio", en S. Ramallo (ed.), La decoración arquitectónica de las ciudades romanas de occidente, Actas del Congreso Internacional: 337-353. Cartagena (2003), Murcia, Universidad de Murcia.

Márquez, C. (2009): "Transformaciones en los foros de Colonia Patricia", en J. M. Noguera (ed.), Fora Hispaniae. Paisaje urbano, arquitectura, programas decorativos y culto imperial en los foros de las ciudades hispanorromanas: 105-121. Murcia, Región de Murcia.

Márquez, C. (2014): "El programa iconográfico del foro”, en C. Márquez, J. A. Morena, R. Córdoba y A. Ventura (eds.), Torreparedones, Baena-Córdoba, Investigaciones arqueológicas (2006-2012): 87-97. Córdoba, Universidad de Córdoba, Excmo. Ayuntamiento de Baena.

Noguera, J. M. (1992): "El conjunto escultórico consagrado por el "dispensador Albanus", algunas puntualizaciones para su estudio iconográfico y estilístico". Verdolay. Revista del Museo arqueológico de Murcia 4: 75-98.

Noguera, J. M. (2001-2002): "Técnicas en la escultura romana: materiales, imprimaciones y coloraciones. A propósito del grupo escultórico de Mazarrón". Anales de Prehistoria y Arqueología 17-18: 393-412.

Oliveira, J. y Nogales, T. (coord.) (2005): Imágenes y mensajes. Escultura romana del Museo de Evora. Catálogo de la exposición. Mérida (2005), Évora, Instituto Portugués de Museus.

Olteanu, T. (2011): “Aportaciones sobre el prototipo de la Victoria de la Curia Iulia", en T. Nogales e I. Rodà (eds.), Roma y las provincias: modelo y difusión. Actas del XI Congreso Internacional de Arte Romano Provincial: vol. I, 511-517. Mérida (2009), Roma, L'Erma di Bretschneider.

Ortego, T. (1976): "Excavaciones arqueológicas realizadas en la villa de "Los Quintanares" en el término de Rioseco, Soria". Noticiario Arqueológico Hispánico, Arqueología 4: 359-373.

Ortego, T. (1977): "La villa romana de "los Quintanares" en el término de Rioseco (Soria)", en Symposium Segovia y la Arqueología Romana: 285 292. Segovia (1977), Barcelona, Universitat de
Barcelona, Instituto de Arqueología y Prehistoria, Caja de Ahorros y Monte de Piedad de Segovia.

Presedo Velo, F. (1982): La necrópolis de Baza. Excavaciones Arqueológicas en España 119. Madrid, Ministerio de Cultura.

Portal, F. (2016): El simbolismo de los colores. En la Antigüedad, la Edad Media y los tiempos modernos. Barcelona, José J. de Olañeta.

Peña, A.; Ventura, A. y Portillo, A. (2011): "El templo consagrado al Divus Augustus y su temenos (Forum Novum)", en Córdoba reflejo de Roma. Catálogo de la exposición: 59-67. Córdoba (2011), Córdoba, Ayuntamiento de Córdoba, Consejería de Cultura de la Junta de Andalucía, Fundación Provincial de Artes Plásticas Rafael Botí, Fundación Viana y Universidad de Córdoba.

Portillo, A. (2014-15): “Una posible restauración del templo de la calle Morería en el forum novum de Colonia Patricia en el siglo II". Anales de Arqueología Cordobesa 25-26: 71-82.

Portillo, A. (2015a): "La decoración arquitectónica del templo de la calle Morería en el forum novum de Colonia Patricia”, en Thiasos Monografie X: 251262. Roma, Quasar.

Portillo, A. (2015b): "Estudio arquitectónico del templo de la calle Morería en el forum novum de Colonia Patricia", en J. López (ed.), Actas del $2^{\text {on }}$ Congrés Internacional d'Arqueologia i Món Antic, August $i$ les províncies occidentals. 2000 aniversari de la mort d'August, vol. 2: 75-80. Tarragona (2014), Tarragona, Fundació Privada Mútua Catalana.

Portillo, A. (2015c): "La policromía del templo de la calle Morería en el forum novum de Colonia Patricia". Archivo Español de Arqueología 88: 171-185.

Portillo, A. (2016a): "La importancia del color en la arquitectura pública romana. Testimonios del empleo de marmora y pintura en algunos templos de la Bética". Cuadernos de Arqueología de la Universidad de Navarra 24: 21-48.

Portillo, A. (2016b): “El templo de la calle Morería en el forum novum de Colonia Patricia. Análisis arquitectónico y funcional", Tesis Doctoral, Universidad de Córdoba. Inédita.

Richter, G. (1966): The furniture of the Greeks, Etruscans and Romans. London, Phaidon Press.

Rodríguez, P. (1979): "Esculturas del conventus de Gades-III (*): Matronas sedentes de Cartama (Málaga)". Baetica. Estudios de Arte, Geografia e Historia 2-1: 131-146.

Rodríguez, M. I. (2013): “Aproximación a la iconografía de Niké en el arte griego”. Eikon/Imago 2, 1: 93-112. 
Ruano, E. (1990): “Aproximación a la artesanía del mueble ibérico: Algunas precisiones sobre el trono de la Dama de Baza (Granada)". Cuadernos de Prehistoria y Arqueología de la Universidad Autónoma de Madrid 17: 25-33.

Santos, S. (1955): Memoria de las excavaciones del Plan Nacional, realizadas en Córdoba (19481850). Madrid, Ministerio de Educación Nacional, Dirección General de Bellas Artes y Comisaría General de Excavaciones Arqueológicas.

Santos, M. F. (1998a): "Miróbriga: sua valorização e caracterização". Anales de Arqueología Cordobesa 9: 59-129.

Santos, M. F. (1998b): Miróbriga: Urbanismo e arquitectura. Lisboa, Ministério da Cultura, Instituto Português do Património Arquitectónico.

Silva, N. (2012): “El grifo". Revista Digital de Iconografia Medieval IV, 8: 45-65.
Spawforth, T. (2007): Los templos griegos. Madrid, Akal.

Vasconcelos, J. Leite de (1913): “Aquisições do Museu Etnológico Português”. O Arqueólogo Português XVIII: 131-168.

Ventura, A. (2007): "Reflexiones sobre la arquitectura y advocación del templo de la calle Morería en el forum novum de Colonia Patricia Corduba", en T. Nogales y J. González (eds.), Culto imperial: política y poder: 216-237. Mérida (2006), Roma, L'Erma di Bretschneider.

Ventura, A. (2014): "El foro", en C. Márquez, J. A. Morena, R. Córdoba y A. Ventura (eds.), Torreparedones, Baena-Córdoba, Investigaciones arqueológicas (2006-2012): 69-85. Córdoba, Universidad de Córdoba, Excmo. Ayuntamiento de Baena.

Zanker, P. (2008): Augusto y el poder de las imágenes. Madrid, Alianza. 